\title{
Significance and Roles of Proteus spp. Bacteria in Natural Environments
}

\author{
Dominika Drzewiecka ${ }^{1}$
}

Received: 22 July 2015 / Accepted: 13 December 2015 /Published online: 9 January 2016

(C) The Author(s) 2016. This article is published with open access at Springerlink.com

\begin{abstract}
Proteus spp. bacteria were first described in 1885 by Gustav Hauser, who had revealed their feature of intensive swarming growth. Currently, the genus is divided into Proteus mirabilis, Proteus vulgaris, Proteus penneri, Proteus hauseri, and three unnamed genomospecies 4,5 , and 6 and consists of 80 O-antigenic serogroups. The bacteria are known to be human opportunistic pathogens, isolated from urine, wounds, and other clinical sources. It is postulated that intestines are a reservoir of these proteolytic organisms. Many wild and domestic animals may be hosts of Proteus spp. bacteria, which are commonly known to play a role of parasites or commensals. However, interesting examples of their symbiotic relationships with higher organisms have also been described. Proteus spp. bacteria present in soil or water habitats are often regarded as indicators of fecal pollution, posing a threat of poisoning when the contaminated water or seafood is consumed. The health risk may also be connected with drugresistant strains sourcing from intestines. Positive aspects of the bacteria presence in water and soil are connected with exceptional features displayed by autochthonic Proteus spp. strains detected in these environments. These rods acquire various metabolic abilities allowing their adaptation to different environmental conditions, such as high concentrations of heavy metals or toxic substances, which may be exploited as sources of energy and nutrition by the bacteria. The Proteus spp. abilities to tolerate or utilize polluting compounds as well as promote plant growth provide a possibility of employing
\end{abstract}

Dominika Drzewiecka

domkam@biol.uni.lodz.pl

1 Department of General Microbiology, Institute of Microbiology, Biotechnology and Immunology, University of Łódź, 90-237 Łódź, Poland these microorganisms in bioremediation and environmental protection.

Keywords Natural microflora - Symbionts · Pathogens · Fecal pollution $\cdot$ Bioremediation $\cdot$ PGPR

\section{Introduction}

\section{Proteus Like in Homer's Poem...}

Microorganisms belonging to the genus Proteus were first described in 1885 by a German microbiologist Gustav Hauser, who had revealed their ability to swarm on solid surfaces. The name Proteus came from Homer's "Odyssey" and its character Proteus, who could change his shape and had an ability of endless transformation. Hauser described two species of the genus: Proteus vulgaris and Proteus mirabilis [81]. The swarming ability, connected with a change of short swimmer cells into long, poli-nucleous and hyper-flagellated swarmer cells, is especially visible in the second species. This is a possible source of the name of $P$. mirabilis, which in Latin means amazing, marvelous, splendid. Hauser might have considered P. vulgaris to be more common and ordinary; therefore, he gave it the Latin name meaning widespread, usual. The ability of swarming growth is used in a simple and effective Dienes test to differentiate Proteus spp. strains with discriminatory power comparable to ribotyping [114]. The phenomenon described by Dienes in 1946 consists in forming boundaries between the swarming growth of different strains, while isogenic strains merge with each other (Fig. 1). However, the background of the expression of the territorial competition between two swarming non-isogenic strains still remains unclear $[8,48]$. The formation of the boundaries (Dienes lines) may depend on different profiles of produced proticines 


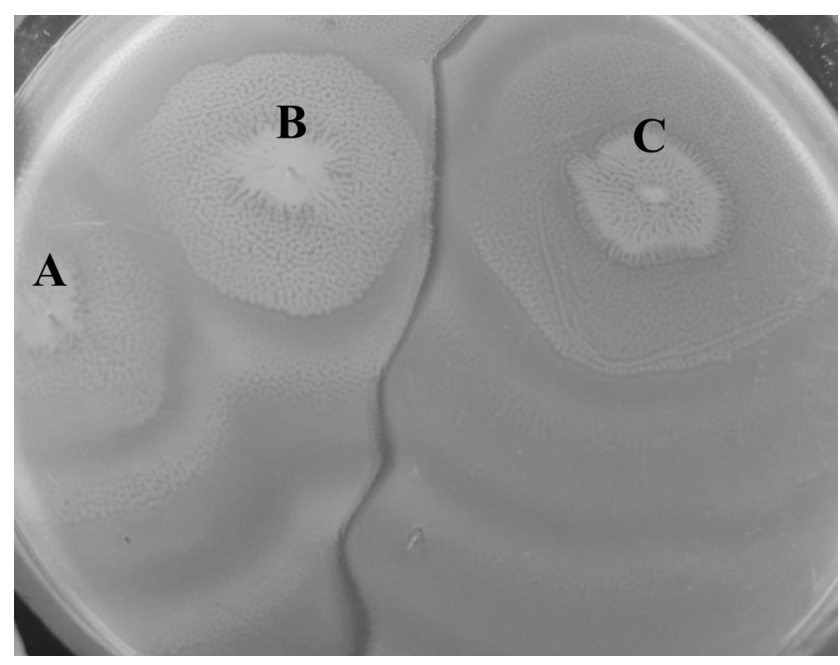

Fig. 1 P. mirabilis strains swarming on the surface of an agar plate: isogenic $\mathrm{A}$ and $\mathrm{B}$ (no line of demarcation is visible) versus unrelated $\mathrm{C}$ (clear Dienes line of demarcation)

(Proteus bacteriocines) and different profiles of strain sensitivity [129]. Budding et al. [19] suggested that one of the meeting strains dominated over the other killing it in the cell-cell contact because round dead cells were observed near the border in the swarm of the dominated strain. The Dienes reaction is connected with at least three recognized gene clusters enabling the self-recognition of $P$. mirabilis bacteria. Two of them (idr and $t s s$ ) encode cytotoxins and a type VI secretion system, respectively [151], while the third one (ids) encodes the Ids proteins responsible for self-identification [21, 49]. However, the mutation in the $i d s$ genes does not provoke the killing of parent or mutant strain cells, although the Dienes line is visible between their swarms [48].

The genus Proteus includes Gram-negative, facultative anaerobic, heterotrophic, and proteolytic rods being human opportunistic pathogens. The taxonomic classification of these bacteria has changed several times. Lately, the only Proteus species with no clinical significance, Proteus myxofaciens, has been postulated to be moved from the genus Proteus to a new genus Cosenzaea [47]. Among other changes, the exclusion from the genus Proteus of several species that created new genera Providencia and Morganella is worth mentioning. These three closely related genera have formed the tribe Proteeae in the family Enterobacteriaceae [81]. Currently, the genus Proteus consists of $P$. mirabilis, $P$. vulgaris, Proteus penneri, Proteus hauseri, and three genomospecies 4, 5, and 6. P. hauseri as well as the genomospecies were separated from $P$. vulgaris on the grounds of molecular studies and form $P$. vulgaris group. The genomospecies 4,5 , and 6 are marked only with numbers as there have been no metabolic properties indicated to allow their full differentiation [104]. The main biochemical features typical of the genus and distinguishing Proteus species are summarized in Table 1.
Table 1 The main metabolic characteristics of Proteus spp. [103, 104]: “+”positive in $100 \%$ strains; "-"negative in $100 \%$ strains; in the other cases, the percentage of strains exhibiting positive reaction is given in parentheses

\begin{tabular}{lllll}
\hline Feature mirabilis & P. penneri & P. vulgaris & P. hauseri & $\begin{array}{l}\text { P. genomospecies 4, 5, } \\
\text { and } 6\end{array}$ \\
\hline
\end{tabular}

\begin{tabular}{llllll}
\hline \multirow{7}{*}{ Typical of the genus and distinguishing it from the other } & \multicolumn{7}{l}{ Enterobacteriaceae } \\
Phenylalanine deaminase & $+(98 \%)$ & $+(99 \%)$ & + & + & + \\
Lysine decarboxylation & - & - & - & - & - \\
Arginine hydrolysis & - & - & - & - & - \\
Urease production & $+(98 \%)$ & + & $+(86 \%)$ & + & + \\
Glucose fermentation & + & + & + & + & + \\
Mannose fermentation & - & - & - & - & - \\
Lactose fermentation & $-(2 \%)$ & $-(1 \%)$ & - & - & - \\
Methyl-red & $+(97 \%)$ & + & $+(86 \%)$ & + & + \\
Growth in KCN & $+(98 \%)$ & $+(99 \%)$ & $+(99 \%)$ & + & $+(97 \%)$ \\
Tyrosine clearing & $+(91 \%)$ & + & + & + & + \\
Typical of the species and allowing their differentiation & & & + \\
Ornithine & $+(99 \%)$ & - & - & - & - \\
decarboxylation & $-(2 \%)$ & - & + & + & + \\
Indole production & $+(92 \%)$ & $-(35 \%)$ & $-(14 \%)$ & - & $+(97 \%)$ \\
Lipase production & $+-(50 \%)$ & $-(12 \%)$ & + & - & $+(85 \%)$ \\
DNase production & - & $+(96 \%)$ & + & + & + \\
Maltose fermentation & $-(15 \%)$ & + & + & + & + \\
Sucrose fermentation & - & - & + & - & $-(3 \%)$ \\
Salicin fermentation & - & - & + & - & $-(3 \%)$ \\
Esculin hydrolysis & $+(65 \%)$ & - & $-(29 \%)$ & - & - \\
Citrate utilization & & & & & + \\
\hline
\end{tabular}


Bacteria from the genus Proteus can also be differentiated on the basis of their O-antigen variability, although serotyping is not included in the routine diagnostics of these rods. So far, there have been established $80 \mathrm{O}$-antigenic serogroups in the genus, some of them divided into subgroups [7, 67, 135], and many new $\mathrm{O}$ serotypes are still being discovered (D. Drzewiecka, unpublished data). The chemical structure of the sugar part of the lipopolysaccharide may play an important role in the adaptation of Proteus spp. bacteria to environmental conditions and enhancing their pathogenicity, as some $\mathrm{O}$ serotypes are more prevalent and more frequently isolated from clinical sources than the others (Table 2) [7, 35, 37, 72, 111, 133].

Proteus spp. bacteria have been isolated from different human and non-human environments and their presence in higher organisms, soil, and water is well documented. However, their specific features and roles played in their natural habitats have not been summarized so far.

\section{Human Beings and Proteus Bacteria-Commensals and Parasites}

Proteus spp. bacteria are mostly known as opportunistic human pathogens. Their roles in the pathogenesis of human beings as well as their virulence factors enabling the bacteria to reach different niches of the host organism and survive have been extensively studied and reviewed $[8,36,81,89,103,124,125]$ and are summarized in Table 2. The bacteria cause infections mainly in people with an impaired immunity system, and most all of them may be a source of complicated urinary tract and wound infections as well as nosocomial infections.
Urinary tract infections are most frequently ascending, often connected with the presence of urinary catheters. It should be noticed that Proteus spp. are the most prevalent bacteria, isolated from bladder and kidney stones ( $70 \%$ of cases). P. mirabilis is the main cause of all Proteus spp. infections accounting for $80-90 \%$ of them.

It is postulated that human intestines are a reservoir of Proteus bacteria, especially those belonging to prevailing P. mirabilis species, and they are members of natural fecal microflora of several percent of human population [124]. Lately, Porres-Osante et al. [118] reported the presence of Proteus spp. bacteria (one P. mirabilis and one P. vulgaris strain) in fecal samples from $4 \%$ of healthy Spanish volunteers. Zilberstein et al. [160], using cultivation methods to study the microbiota in particular parts of the digestive tract, stated that Proteus spp. bacteria were absent from the mouth and the esophagus of healthy volunteers. However, the bacteria were present in comparatively high mean concentrations in the stomach of $8.1 \%$ of volunteers $\left(10^{5}\right.$ colony forming units $\left.(\mathrm{CFU}) / \mathrm{mL}\right)$, the duodenum $\left(45.5 \%, 10^{2}\right)$, the proximal jejunum $\left(45.5 \%, 10^{4}\right)$, the proximal ileum $\left(20 \%, 10^{6}\right)$, the distal ileum $\left(19 \%, 10^{3.5}\right)$, the cecum $\left(12.5 \%, 10^{4}\right)$, the colon (ascending, $33.3 \%$, $10^{5}$; transverse, $37.5 \%, 10^{5}$; descending, $25 \%, 10^{5}$; and sigmoid, $\left.34.8 \%, 10^{7}\right)$, and in the rectum $\left(30 \%, 10^{7}\right)$. The other members of the family EnterobacteriaceaeEscherichia coli, Enterobacter spp., and Klebsiella spp.-were detected in the same places in the lower digestive tract, but they were more prevalent.

Proteus spp. are regarded to be an undesired element of intestinal microflora, as the bacteria may also become a causative agent of diarrhea. Although Ikeobi et al. [59] did not notice significant differences in the presence of

Table 2 Pathogenicity of Proteus spp. rods to humans [7, 8, 35, 37, 72, 81, 111, 125, 133, 148]

\begin{tabular}{|c|c|c|}
\hline Infections & Virulence factors & Prevalent O-serotypes \\
\hline $\begin{array}{l}\text { - Urinary tract infections (cystitis, prostatitis, } \\
\text { pyelonephritis, kidney stone formation) } \\
\text { - Wounds and burns infections, abscesses } \\
\text { - Respiratory tract infections } \\
\text { - Bacteremia } \\
\text { - Meningitis } \\
\text { - Intestine colonization (diarrhea) } \\
\text { - Nosocomial infections } \\
\text { - Rheumatoid arthritis (?) - autoaggressive antibodies } \\
\text { may arise due to the molecular mimicry between } \\
\text { Proteus hemolysin and urease, and human white } \\
\text { blood cells }\end{array}$ & $\begin{array}{l}\text { - Fimbriae - adhesion } \\
\text { - Flagella - swimming, swarming growth } \\
\text { - Urease - urine pH elevation, kidney stones } \\
\text { formation } \\
\text { - LPS - endotoxin } \\
\text { - O and capsular polysaccharides - swarming } \\
\text { facilitation, kidney stones and biofilm } \\
\text { formation, serospecificity } \\
\text { - Biofilm - protection } \\
\text { - Invasiveness - internalization into host cells } \\
\text { - Haemolysins - cytotoxicity } \\
\text { - Proteus toxic agglutinin - cell-cell aggregation, } \\
\text { cytotoxicity } \\
\text { - Proteases - antibodies degradation } \\
\text { - Deaminases - } \alpha \text {-keto-acid siderophores } \\
\text { production and iron acquisition } \\
\text { - Zinc and phosphate transport systems - utilization }\end{array}$ & $\begin{array}{l}\text { - O3, O6, O10, O11, O13, O23, O24, O27, } \\
\text { O28, O29, O30 - including P. mirabilis } \\
\text { and } P \text {. vulgaris strains } \\
\text { - O17, O61, O64, O65 - including } \\
\text { P. penneri strains mainly } \\
\text { - O78 - including P. mirabilis strains } \\
\text { (data only from Poland) } \\
\text { - O79 including P. genomospecies strains } \\
\text { (data only from Poland) }\end{array}$ \\
\hline
\end{tabular}


Proteeae members in the intestines of healthy individuals and diarrheal patients, Müller [91, 92] isolated $P$. mirabilis strains statistically more frequently from feces of patients suffering from diarrhea than from healthy individuals. The author suggested that the bacteria may become opportunists when the illness is caused by other intestinal pathogens or they may lead to intestinal disorders independently. Also, P. penneri strains were more frequently isolated from sick than from healthy people, while $P$. vulgaris were present in almost the same number of individuals in each group.

Thus, the presence of Proteus spp. bacteria in the gastrointestinal tract may also be treated as a carrier state, because in some conditions, it may lead to cross-infections and autoinfections especially in the urinary tract, which was observed many years ago by de Louvois [73] using serotyping as well as the Dienes test and confirmed in other studies $[8,48]$. Chow et al. [26] emphasized the role of the intestinal tract as a reservoir of $P$. mirabilis bacteria leading to person-to-person transmitted nosocomial infection. Drzewiecka et al. [34, 35], by the use of serological and molecular methods as well as the Dienes test, proved that P. mirabilis strains isolated from feces and urine of patients were in fact the same spreading clone causing autoinfection and nosocomial infection. Wang et al. [148] reported the case of food poisoning in a restaurant in Beijing, China, caused by P. mirabilis. The same clone, identified by genotyping and the Dienes method, was detected in the consumed food and in stools of consumers as well as the cook handler and the waiter who, due to the lack of hygiene, most probably had transported the bacteria to the meal. The fact that dirty hands may be an important step in feces-tohand-to-mouth spread of Proteus spp. bacteria was also confirmed by other researchers. Smith et al. [136] found $P$. vulgaris among the bacteria and yeasts isolated from roadside telephone receivers in Lagos, Nigeria. Padaruth and BiranjiaHurdoyal [110] detected Proteus spp. on hands of primary school pupils in Mauritius while Shojaei et al. [132] on hands of food handlers in Iran (but simple washing resolved the problem). Also, Qadripur et al. [119] found P. mirabilis to colonize hand skin between nail plate and nail fold in motor mechanics.

Peerbooms et al. [113] compared P. mirabilis strains isolated from urine and feces, and all the isolates seemed to display similar virulence potential, which confirmed that the strains attacking the urinary tract may come from the intestinal reservoir. Also, Senior and Leslie [130] concluded that frequent isolation of $P$. mirabilis from feces and rare occurrence of $P$. vulgaris in the intestines of healthy individuals and those suffering from gastroenteritis may explain the fact that it is the first species and not the second one that is strongly connected with urinary tract infections.

The presence of $P$. mirabilis in the intestines may also be connected with obesity. Lecomte et al. [74], conducting research on an animal model, have recently reported on the changes in gut microflora depending on diet. Studying the intestinal microbiota of rats fed a high-fat diet (43 or $51 \%$ of fat), the authors noticed higher numbers of $P$. mirabilis as compared to the control group (12\% fat diet). Moreover, a significant positive correlation was found between the abundance of P. mirabilis (as well as Phascolarctobacterium and Veillonellaceae) and all ten analyzed metabolic parameters associated with obesity.

\section{Proteus spp. in Animals-Adverse and Friendly}

Not only rats but also many wild and domestic animals (mammals, birds, reptiles, amphibians, insects, and "seafood") are the hosts of Proteus spp. bacteria. The relation of the bacteria to their host organism is sometimes not determined; in some cases, it may be symbiotic or change from neutral/commensal to parasitic (Table 3). The microorganisms are an element of animal pathogenic or physiological microflora, especially in the intestines - a reservoir of the bacteria.

P. mirabilis and P. vulgaris were found in fecal samples of western lowland gorillas (Gorilla gorilla gorilla), collected at two locations in south-central Cameroon, proving to inhabit the intestines of these great wild apes [15]. Like in humans, the presence of Proteus spp. in animal intestines may pose a threat of autoinfection and cross-infection. The example of such autoinfection was described by Gaastra et al. [44], who in the Netherlands isolated P. mirabilis strains from feces and urine of dogs suffering from recurrent urinary tract infections. It is probable that the intestine was a reservoir of the bacteria infecting the urinary tract of the dogs, because $P$. mirabilis strains were not isolated from feces of healthy controls. Also, Kroemer et al. [69] reported $P$. mirabilis strains as a reason for urinary tract infections in dogs and cats in European countries. Normand et al. [99] indicated Proteus spp. isolated from different materials (mostly feces, urine, skin swabs, upper respiratory tracks) as an important cause of illness in dogs and cats examined in Glasgow, UK. Moreover, $26 \%$ of the strains were identified as multiple drug resistant. $P$. mirabilis was isolated from the rectum, the vagina, the mouth, the nose, and wound/abscess of feral cats analyzed in Grenada, West Indies [54]. However, all the isolates were sensitive to most of the used antibiotics, so it was concluded that feral cats did not pose a risk to humans or other cats. Kitamikado and Lee [66] isolated from feces of raccoon dog Nyctereutes procyonoides, a $P$. vulgaris strain producing chondroitinase, which may be regarded as one of the virulence factors produced by the microorganism because chondroitin sulfate is distributed in animal connective tissues.

On the other hand, there was no connection found between Proteus spp. and ulcerative keratitis [146] or transmissible venereal tumor [38] in dogs, as P. penneri and P. vulgaris 
Table 3 Different kinds of relationship between Proteus spp. and other organisms (details in the text): "+" positive (beneficial), "?" neutral/commensal/not determined, "-" negative (antagonistic, pathogenic)

\begin{tabular}{|c|c|c|c|c|c|}
\hline organisms & $\begin{array}{l}\text { Proteus } \\
\text { sp. }\end{array}$ & P. mirabilis & $\begin{array}{l}P \text {. vulgaris } \\
\text { group }\end{array}$ & P. penneri & selected references \\
\hline Humans & & $? /-$ & $? /-$ & $? /-$ & $8,36,81,103,124,125,148$ \\
\hline Gorillas & & $?$ & $?$ & & 15 \\
\hline Dogs & - & $? /-$ & $?$ & $?$ & $38,44,69,99,144$ \\
\hline Cats, feral cats & - & - & & & $54,69,99$ \\
\hline Pigs & & $?$ & $?$ & & $68,75,147$ \\
\hline Horses & $? /-$ & & & & 84,152 \\
\hline Donkeys & - & & & & 83 \\
\hline Cow, cattle, calf & & $?$ & $? /-$ & $?$ & $2,56,76,123,138$ \\
\hline Raccoon dog & & & $?$ & & 66 \\
\hline Flying fox & & + & + & & 6 \\
\hline Rats & & $?$ & & & 73 \\
\hline Birds, poultry & $-($ eggs $)$ & $? /-$ & $? /-$ & $? /-$ & $\begin{array}{l}9,43,46,61,62,68,71,123,154 \\
\quad 155,161\end{array}$ \\
\hline Snakes & & $?$ & $?$ & $?$ & $16,53,131$ \\
\hline Alligator & - & & & & 101 \\
\hline Turtles & - & $?$ & $? /-$ & $? /-$ & $5,10,42,53,102,108,127$ \\
\hline Amphibians & & & $?$ & & 53 \\
\hline Fishes & $+/ ?$ & + & $+/ ? /-$ & + & $17,66,70,97,107,141$ \\
\hline Oysters & & $?$ & & & 39 \\
\hline Shrimps & $+/ ?$ & $+/ ?$ & $+/ ?$ & $+/ ? /-$ & $20,82,97,98$ \\
\hline Lobsters & + & + & + & + & 97 \\
\hline Blue crab & & & & $?$ & 109 \\
\hline Sponges & & $+/ ?$ & $?$ & & 50,64 \\
\hline Millipede & & + & & & 4 \\
\hline Lepidopteran & & & - & & 85 \\
\hline Cockroaches & & $?$ & $?$ & & $142,145,149$ \\
\hline Honey bees & $?$ & & & & 137 \\
\hline Flies & $?$ & $? /+$ & $?$ & & $\begin{array}{l}18,51,79,80,85,87,94,134,144 \\
\quad 150\end{array}$ \\
\hline Mites & & & + & & 2 \\
\hline Nematodes & & & & - & 76 \\
\hline $\begin{array}{l}\text { Leguminous } \\
\text { plants }\end{array}$ & & & + & & $12,14,120$ \\
\hline Wild grass & & + & & & 121 \\
\hline Tea & & & + & & 12 \\
\hline Cabbage & & & + & & 156 \\
\hline Maize & & + & & & 60 \\
\hline Mould fungi & - & & - & & 11,12 \\
\hline C. albicans & & - & & & 50 \\
\hline B. bacteriovorus & & & & - & 20 \\
\hline
\end{tabular}

strains were isolated from the eyes of healthy dogs in Beijing, China, and, respectively, $P$. mirabilis from the vagina of a healthy dog in Nigeria, but not from sick animals.

Proteus spp. bacteria may also be the members of natural microflora of the esophagus [84] and the skin of horses, although they were also isolated from wounds [152]. However, the wound isolates displayed strong adherence and significantly stronger attachment than skin isolates proving enhanced virulence of pathogenic strains, as compared to normal skin isolates. The bacteria are virulent also to donkeys causing urinary tract infections. They were found to account for $6.7 \%$ of donkey uropathogens isolated in Ethiopia, among which Streptococcus spp. (43.3\% isolates) and E. coli $(20 \%)$ were dominating [83].

$P$. mirabilis and $P$. vulgaris were also detected as the elements of the microbial community in pigs. Lowe et al. [75] 
revealed that the family Enterobacteriaceae was a minor but significant component of pig tonsil microflora in which $P$. mirabilis or $P$. vulgaris clones dominated. Wang et al. [147] reported a $P$. vulgaris strain isolated from nasal swab of a pig from a food producing animal farm (sic!) that was carrying a chromosomally located staphylococcal multiresistance $c f r$ gene encoding the resistance to linezolid, but also to other chemically unrelated classes of antimicrobial agents. The gene was for the first time reported in a naturally occurring Gramnegative bacterium. Still Kobashi et al. [68] isolated $P$. mirabilis strains from pig feces detecting the efflux genes responsible for their resistance to tetracycline (tetH and tetJ).

All Proteus species were detected in the cow. Hawkey et al. [56] revealed that $P$. vulgaris (including the strains currently numbered among genomospecies) as well as $P$. mirabilis species were, respectively, the first and the third species among the tribe Proteeae most commonly isolated from beddings contaminated with feces and urine in two calf farms in South West England. The authors concluded that the high similarity of the O-serotype profile of isolated strains (e.g., serotypes $\mathrm{O} 23$ and $\mathrm{O} 30$ ) to those reported for human infections (Table 2) suggests that food animals may be a source of Proteeae strains carried in human gut. Lu et al. [76] reported on the isolation from a cow dung in China of P. penneri strains displaying strong nematicidal activity. $P$. vulgaris seems to belong to normal skin microflora of cattle, but the involvement of these bacteria in the damage to tissues around the skin lesions caused by Demodex bovis mite and their synergistic influence was also revealed [2]. The symbiosis between the parasites relies on the fact that the mite introducing the bacteria into the skin on the exoskeleton or in the gut receives suitable microclimate for the establishment and replication due to many virulence factors and enzymes produced by the cooperating microorganisms.

Rogers [123] suggested a possibility of the transmission of potentially pathogenic bacteria, including Proteus spp., between wild birds and cattle. The author stated the presence of $P$. vulgaris in feces of $13 \%$ dairy cattle in five studied farms, and in fecal and cloacal samples from $7.8 \%$ analyzed birds (sparrows, blackbirds, cowbirds, but not starlings).

Other authors also emphasized the role of wild birds in the transmission and spread of pathogenic bacteria to domestic poultry, cattle, or humans, resulting in the change of their status from bird fecal microflora members to the etiological agent of pathogenesis. Yong et al. [155] found P. mirabilis to be prevalent in feces of large-billed crows (Corvus spp.) inhabiting the surroundings of a minimarket in Bangsar, Malaysia, and becoming a health hazard due to their large numbers. However, no bacteria (with the exception of Klebsiella spp.) were present in the air samples from the market place. Winsor et al. [154] conducted studies on fecal microflora of apparently healthy wild turkey vultures (Cathartes aura) in Texas, USA, because the diet of these birds, which are carrion- feeding animals, must include animals that have died of infectious diseases. The content of the studied bird intestines was dominated by E. coli but, in fact, P. mirabilis was the second predominant species detected in $50 \%$ birds and $P$. vulgaris was isolated from one bird. Jahantigh $[61,62]$ stated that Proteus spp. strains in 2010 accounted for $5 \%$ and in 2012 for $12.5 \%$ isolates from eggs of the ostrich (Struthio camelus). The authors indicated fecal contamination that may lead to the penetration of the bacteria into the egg interior and the infection which may be a reason for a relatively high ratio of embryonic mortality in ostrich eggs in Iran. Awad-Alla et al. [9] suggested a possible role of white ibises (Nipponia nippon) in Egypt in the transmission of some pathogens to poultry as in the internal organs of apparently healthy birds they found several strains classified as $P$. mirabilis (although the indicated ability of indole production suggests that the strains should be identified as $P$. vulgaris; see Table 1). Next, Foti et al. [43] conducted studies on the health status of birds belonging to several orders migrating to Africa through the Ustica Island (Italy). From fecal swabs and internal organs of birds found dead, they isolated only one P. mirabilis strain, so the probability of dissemination of these bacteria was very low. Kwiecińska-Piróg et al. [71] revealed that P. mirabilis naturally occurring in the crop and the cloaca of white stork (Ciconia ciconia) healthy nestlings in Poland were more susceptible to antibiotics than clinical strains isolated from human beings and no ESBL production was detected.

The above data indicate that the presence of Proteus spp. in birds does not pose a real risk of dissemination; moreover, Proteus spp. bacteria seem to be a member of normal poultry microflora. Among the bacteria inhabiting the beak cavity and the cloaca of reproductive goose flocks (190-800 birds) from 17 farms in Poland, Proteus spp. colonized approximately 10 $25 \%$ of birds [161], while E. coli, Enterococcus spp., and Streptococcus spp. were found in approximately $60-70 \%$ of birds and coagulase-negative Staphylococcus was isolated from $80-90 \%$ birds, independently of the sampling site. Other bacteria were isolated sporadically. Also, Kobashi et al. [68] isolated P. mirabilis and Proteus sp. strains from poultry feces, detecting the tet $M$ gene, encoding their resistance to tetracycline. However, Giacopello et al. [46] recognized antibioticresistant $P$. mirabilis, $P$. vulgaris, and $P$. penneri present in feces of sick domestic canaries as pathogenic microflora.

Proteus spp. colonize also amphibians and reptiles, e.g., $P$. vulgaris is reported as a common inhabitant both in the oral cavity and in the cloaca of water amphibians (Lissotriton vulgaris newts and Pelophylax ridibundus frogs) and reptiles (Mauremys rivulata turtles and Natrix natrix grass snakes) inhabiting the Kavak Delta, Turkey [53]. In the oral bacterial flora of Chinese cobra, Naja atra, and bamboo pit vipers, Thimeresurus albolabris, two snake species common in Hong Kong [131], P. penneri, P. vulgaris, and P. mirabilis strains were isolated among many other potentially pathogenic 
bacteria. Blaylock [16] reported on the common isolation of Proteus sp., P. mirabilis, and P. vulgaris from oral swabs of four different house snake species from southern Africa. There is also a report on pathogenic Proteus sp. as a cause (together with Morganella morganii) of the septicemia and death of a captive alligator held in the Savannah River Ecology Laboratory in Aiken, SC, USA [101].

There are several reports available concerning the presence of Proteus spp. bacteria in water turtles, sometimes connected with illness. They were the fourth genus most frequently isolated from lesions of sea turtles from the Canary Islands, Spain, and were considered as one of the causes of their diseases and mortality [108]. Al-Bahry et al. [5] interpreted the presence of Proteus spp. and P. vulgaris (resistant to ampicillin, streptomycin, and tetracycline) in oviductal fluids of nesting sea green turtles (Chelonia mydas) as an indicator of pollution in the surrounding areas between the Gulf of Oman and the Arabian Sea (see the next paragraph). In contrast, in nesting green turtles from Costa Rica, $P$. mirabilis and $P$. vulgaris bacteria were recognized as a non-pathogenic constituent of microflora. They were isolated from nasal and cloacal swabs from apparently healthy turtle females with no signs of disease. There was no correlation observed between the turtles and seawater bacteria composition, so it was suggested that Proteus bacteria should be treated as the physiological microflora of green turtles [127]. P. mirabilis was also commonly found as inhabiting the cloaca of European pond turtles (Emys orbicularis), especially captive ones, from Poland [102]. P. vulgaris was the predominant species, and some $P$. mirabilis strains were also identified in cloacal and oral swabs of loggerhead sea turtles (Caretta caretta) inhabiting the Sicilian Channel, the South Tyrrhenian Sea, and the Ionian Sea [42]. The loggerhead turtle is included in the Red List of the world conservation union, and the microbial contamination of the turtle eggs is suspected to play a role in embryonic death and a low loggerhead hatch success rate in Georgia, USA. Indeed, among other Gram-negative isolates from unhatched eggs of the turtle on Jekyll Island, Georgia, P. penneri and $P$. vulgaris strains were identified [10].

Although Proteus spp. bacteria are commonly known as opportunistic pathogens, there can be found interesting examples of positive relations between the microorganisms and the host animal (Table 3). P. mirabilis and P. vulgaris strains isolated from the intestine of the Indian flying fox (Pteropus giganteus) were recognized as the members of symbiotic physiological microflora of this big fruit bat [6]. Although this is unusual for the two species (Table 4), the isolates were able to produce cellulolytic and xylanolytic enzymes just as three other isolated species, Citrobacter freundii, Serratia liquefaciens, and Klebsiella oxytoca, and contrary to the other six gut isolates unable to digest cellulose. Fruits and leaves, which are the animal's main food, are built of up to $50 \%$ of cellulose, hemicellulose (xylan), lignocellulose, and pectin cellulose, and because mammals do not possess proper enzymes to degrade the polymers, the symbiotic enterobacteria play an essential role in their nourishment and digestion. Another example of a cellulolytic and xylanolytic P. mirabilis strain isolated as a gut symbiont of millipede (Xenobolus carnifex) was reported by Alagesan et al. [4].

Also, a symbiotic role has been suggested for $P$. mirabilis and $P$. vulgaris isolated from hematophagous sand fly Phlebotomus papatasi being a vector of Leishmania parasite, as the bacteria were the most prevalent in larvae, pupae, and mature male and female insects gut [80]. Another very interesting hypothesis indicating a close relationship between $P$. mirabilis and its blowfly host Lucilia sericata was formed by Ma et al. [79]. These proteolytic microorganisms are able to produce volatile components, for example, putrescine (from ornithine) and ammonia (see Table 1), important for their swarming ability and, at the same time, attracting flies to the carcass. The authors stated that putrescine, which is an extracellular signal required for the swarming phenomenon and used by P. mirabilis in quorum sensing [89], may be an interkingdom signal sensed by both the insects and the bacteria. The same role was suggested for ammonia. Both compounds as well as four other attractants $(\mathrm{NaOH}, \mathrm{KOH}$, phenol, and lactic acid) restored the swarming motility in different swarming-deficient mutants of the P. mirabilis strain isolated from maggot salivary glands where they dominated, so the researchers linked fly attraction with Proteus swarming. The bacteria were detected also in adult $L$. sericata flies and in Lucilia cuprina sister species [134]. The symbiosis between blowflies and Proteus bacteria is also indicated by the fact that P. mirabilis biofilm, contrary to biofilms constructed by Staphylococcus aureus and Enterobacter cloacae, is not disrupted or is even stimulated by L. sericata maggots used in the debridement therapy. Simultaneously, P. mirabilis is antagonistic to some bacteria eliminated by maggots from wounds, protecting the larvae from harmful microorganisms [18]. Complete sterility of L. cuprina maggots for wound therapy was achieved in all cases except for P. mirabilis [87]. Additionally, Wei et al. [150] revealed that both sensitive and antibiotic-resistant $P$. mirabilis strains could persist for several days among the gut microflora of the green bottle fly (L. sericata) or the housefly (Musca domestica L.) when introduced by feeding. It has been speculated that the mechanisms stimulated by the fly host may contribute to the maintaining of antibiotic-resistant strains in particular, and in that way, their transmission is imminent. It was also suggested [144] that flies, as the vectors of bacteria to raw meat devoted to dog breeding, were responsible for a high percentage of morbidity and mortality due to intestinal infections among pups in greyhound dog kennels in Kansas, USA. A high percentage of bacterial contamination among blowflies (different species) and domestic flies ( $M$. domestica), stable flies (Stomoxys calcitrans L.), flesh flies, and others was observed, 
Table 4 Unusual physiological features displayed by Proteus spp. strains isolated from different habitats (details in the text)

\begin{tabular}{|c|c|c|c|c|}
\hline Feature & Proteus sp. & P. mirabilis & P. vulgaris & P. hauseri \\
\hline Heterotrophic nitrification & & Coastal seawater & & \\
\hline Cellulose digestion & & Flying fox, millipede & Flying fox & \\
\hline $\begin{array}{l}\text { Lipase production/ } \\
\text { hydrocarbons utilization } \\
\text { (including aromatic ones) }\end{array}$ & $\begin{array}{l}\text { Contaminated } \\
\text { soil; waste } \\
\text { sludge }\end{array}$ & Contaminated soil & $\begin{array}{l}\text { Contaminated } \\
\text { soil; } \\
\text { contaminated } \\
\text { fish }\end{array}$ & \\
\hline Phenol utilization & & Contaminated soil & & \\
\hline $\begin{array}{l}\text { Methyl tert-butyl ether (MTBE) } \\
\text { degradation }\end{array}$ & & Contaminated soil & & \\
\hline$\varepsilon$-Caprolactam utilization & & Contaminated soil & & \\
\hline $\begin{array}{l}\text { Hexachlorocyclohexane }(\mathrm{HCH}) \\
\text { pesticide utilization }\end{array}$ & $\begin{array}{l}\text { Contaminated } \\
\text { soil }\end{array}$ & & & \\
\hline Phorate pesticide utilization & $\begin{array}{l}\text { Contaminated } \\
\text { soil }\end{array}$ & & & \\
\hline $\begin{array}{l}\text { Chlorpyrifos, methyl parathion, } \\
\text { and p-nitrophenol pesticides } \\
\text { degradation }\end{array}$ & $\begin{array}{l}\text { Contaminated } \\
\text { soil (in } \\
\text { consortium) }\end{array}$ & $\begin{array}{l}\text { Contaminated soil (in } \\
\text { consortium) }\end{array}$ & & \\
\hline DDT reduction & & & Mouse & \\
\hline Azo dyes decolorizing & Waste site & $\begin{array}{l}\text { Contaminated soil; } \\
\text { wastewater sludge }\end{array}$ & & $\begin{array}{l}\text { Hot } \\
\text { spring }\end{array}$ \\
\hline Phosphate solubilization & $\begin{array}{l}\text { Phorate } \\
\quad \text { contaminated } \\
\text { soil }\end{array}$ & $\begin{array}{l}\text { Wild grass } \\
\text { rhizosphere }\end{array}$ & & \\
\hline Copper tolerance & & $\begin{array}{l}\text { Wild grass } \\
\text { rhizosphere; } \\
\text { wastewater }\end{array}$ & Soil & $\begin{array}{l}\text { Hot } \\
\text { spring }\end{array}$ \\
\hline $\begin{array}{l}\text { Chromium,cobalt, cadmium, } \\
\text { zinc,mercury, nickel, lead, } \\
\text { arsenic tolerance }\end{array}$ & & $\begin{array}{l}\text { Wild grass } \\
\text { rhizosphere; } \\
\text { wastewater; } \\
\text { contaminated soil }\end{array}$ & & \\
\hline Silver tolerance & & Wastewater & & \\
\hline Chromate tolerance & $\begin{array}{l}\text { Contaminated } \\
\text { seawater }\end{array}$ & & & \\
\hline Thermotolerance & & & & $\begin{array}{l}\text { Hot } \\
\text { spring }\end{array}$ \\
\hline Halotolerance & Salt lake & Oysters & $\begin{array}{l}\text { Halophyte } \\
\text { glasswort } \\
\text { rhizosphere }\end{array}$ & \\
\hline Acidotolerance & $\begin{array}{l}\text { Soil } \\
\text { contaminated } \\
\text { by } \\
\text { hydrocarbons }\end{array}$ & & Acidic soil & $\begin{array}{l}\text { Hot } \\
\text { spring }\end{array}$ \\
\hline
\end{tabular}

while Proteus spp. were proved to be the most common bacteria among Gram-negative and lactose-negative ones isolated from flies, followed by Providencia spp., Pseudomonas spp., and Salmonella spp. Nazni et al. [94] identified Proteus as the second (after Enterobacter) dominating genus on the external body surface, while in the fly gut, Proteus spp. dominated among the bacteria isolated from the housefly ( $M$. domestica) on a poultry farm in Malaysia. P. mirabilis with Providencia spp. was also prevalent in gut microflora of flies captured in different public places in India [51].

Not only flies but also cockroaches are regarded as common vectors of different microorganisms, including $P$. mirabilis and $P$. vulgaris strains, carrying them on their bodies and posing a threat of their dissemination, food contamination, and spoiling as well as infection of humans. The bacteria were found in Nigerian cockroaches in Ekpoma, a village characterized by poor sanitary conditions [142], and in Iranian brown-banded cockroaches collected in kitchens of Ahvaz houses [145]. Wannigama et al. [149] reported on the isolation of $P$. mirabilis from $8.9 \%$ cockroaches found in households and food-handling establishments in Varanasi, India.

P. vulgaris was isolated from tissues of an American fly Drosophila paulistorum [85], although it was not determined if the microorganisms were parasitic, mutualistic, or symbiotic to their host. However, they displayed strong pathogenicity toward lepidopterans like Heliothis virescens. Other insects 
which may carry Proteus spp. bacteria in the intestines are bees [137]. It is suggested that the source of the bacteria is pollen consumption and bees in the colony are infected one by one during food exchange. Honey pollution by Proteus spp. may pose a threat to consumers.

A similar situation may be observed in water animals, so called "seafood," where the presence of Proteus spp. may result in food spoiling and poisoning, e.g., scombroid poisoning of fish meat as a result of histidine decarboxylation leading to a rise in the level of toxic histamine [100]. A source of bacteria, including antibiotic-resistant ones, may be fecally contaminated water (see the next paragraph), because $P$. vulgaris and $P$. mirabilis rods were found as absorbed on body structures of the commercially important sponge Spongia officinalis, an animal inhabiting the Aegean Sea and feeding by the seawater filtration [64]. Also, Graça et al. [50] reported on the isolation of several Proteus sp. strains (closely related to P. mirabilis) from the marine sponge (Erylus deficiens) collected $150 \mathrm{~km}$ off the southwest coast of Portugal. The authors revealed that Proteus sp. strains (together with Pseudoalteromonas and Microbacterium spp. isolates) presented the strongest bioactivity against pathogenic bacteria and Candida albicans, thus protecting the host animal and assisting its survival, also due to the fact that the absorbed bacteria constitute $50-60 \%$ of the sponge biomass.

However, the occurrence of these opportunistic human pathogens in oysters poses a health risk if the shellfish are consumed raw. Fernandez-Delgado et al. [39] found halophilic (growth in saline concentrations from 3 to $8 \%$ ) $P$. mirabilis as prevailing in the bodies of two oyster species in Venezuela and resistant to several tested antibiotics (mainly tetracycline, ampicillin and penicillin, and cefoxitin and cefazolin). Also, Matyar et al. [82] isolated several antibiotic-resistant $P$. vulgaris and $P$. penneri strains from the intestines of shrimps inhabiting the Iskenderun Bay, Turkey, which was most probably due to the Iskedrun Bay contamination by industrial and domestic wastes, including hospital ones. It is worth noting that Proteus spp. strains were absent from seawater and sediments, although high amounts of fecal coliforms indicated strong fecal contamination of the Bay. Nimrat et al. [98] identified Proteus spp. and P. mirabilis among other bacteria detected in spermatophores from black tiger shrimps (Penaeus monodon) collected from the Andaman Sea, Thailand. Cao et al. [20] recognized P. penneri as an agent causing red body disease of commercial white shrimps Penaeus vannamei, cultivated in Xiaoshan, Zheijang, China. Interestingly, the mortality of shrimps was successfully inhibited by the predatory activity of Bdellovibrio bacteriovorus against the P. penneri pathogen; thus, the authors propose this bacterial predator as a potential biocontrol agent. $P$. penneri strain inter alia was also detected on the body surface of the wild blue crab (Callinectes sapidus) in the Akyatan Lagoon (the south of the Mediterranean Sea) [109].

Proteus spp. rods are found in marine fishes. In Atlantic mackerel (Scomber scombrus), P. vulgaris and Proteus sp. were detected in gills, skin, and gut as the only members of the family Enterobacteriaceae [141]. In Scomber japonicus mackerel (the intestine and the stomach) or in Limanda herzensteini flat fish (the gills), P. vulgaris was stated as producing a big yield of intracellular and extracellular chondroitinase, which may be directed against the host connective tissues, containing mucopolysaccharide chondroitin [66]. Also, freshwater Nile tilapias (Oreochromis niloticus) from experimental freshwater aquaculture in Brazil [17] and tilapias from Lake Victoria, Kenya [107], were sporadically colonized by P. vulgaris or Proteus sp. Kumar et al. [70] reported on $P$. hauseri as a causative agent of hemorrhage and mortality in a koi carp (Cyprinus carpio) farm in India. This is the first animal habitat reported for this poorly recognized species, while the sources of isolation of two previously described P. hauseri strains (one human) remain unknown [104] and two other strains were isolated from human urine [63].

The presence of Proteus spp. bacteria was also revealed to have a surprisingly positive influence on water animals. Many P. mirabilis, P. vulgaris, $P$. penneri, $P$. genomospecies 4, and unidentified Proteus sp. strains isolated from the intestines of black tiger shrimp, cobia marine fish, snubnose pompano marine fish, and ornate spiny lobster in Vietnam demonstrated probiotic properties linked to bacteriocin production and their antagonistic activity towards many pathogenic bacteria [97].

\section{Proteus as an Indicator of Fecal Pollution}

The presence of Proteus spp. bacteria in water and soil may indicate the fecal pollution of the environments where these proteolytic bacteria are treated as allochthonic. Human and animal feces are probably an important source of these rods in natural environments. Water animals may absorb pollutant microorganisms from water. There is a potential risk of their spread in the marine food chain as well as dissemination during the food processing and transmission to humans after consumption. For instance, bacteria (in that number Proteus spp.) associated with sponges ( $S$. officinalis), which are the main filter feeders in marine environment, were proposed to be treated as indicators of fecal contamination of marine ecosystems [64]. Other marine animals that are reported to accumulate Proteus spp. from water environment are oysters [39], loggerhead turtles $(C$. caretta) [42], and green turtles $(C$. mydas) [5], although Santoro et al. [127] did not find the 
correlation between green turtle microflora and seawater microorganisms.

Also, antibiotic-resistant Proteus spp. strains may be released from the intestines which are a source of drugresistance genes [126]. Some authors [5, 39, 82] emphasize the fact that marine environment seems to be a reservoir of genes responsible for the antibiotic resistance of polluting bacteria, as many antibiotic-resistant strains, including Proteus spp., are isolated from water and sea animals (see the previous paragraph). A good example is also the Jiaozhou Bay on the western coast of the Yellow Sea, China, which is highly contaminated due to intensive industrial development and urbanization. Effluents from hospitals and wastewater may be the sources of drug-resistant bacteria, allowing the resistance genes transfer to environmental microflora. Many bacterial strains resistant to tetracycline or chloramphenicol, including P. mirabilis, were isolated from the seawater by Dang et al. [28, 29]. Also, in Cameroon studies of water samples collected for a period of 8 months from Douala Lagoon, contaminated by industrial and domestic wastes, resulted in the isolation of $P$. vulgaris strains among other fecal bacteria in each sample, which poses a serious health problem [3].

The fact of Proteus spp. survival in marine environments indicates the ability of these microorganisms to adapt to higher salinity conditions, similarly to the strains from oysters, mentioned earlier. Indeed, several halotolerant Proteus spp. strains were detected in water samples from El Golea Salt Lake, Algerian Sahara, proving that domestic wastes from the ElGoela oasis could be a source of the fecal microflora surviving in these conditions [52].

Proteus spp. can also be found in freshwater, as an indicator of its contamination by feces, even in unexpected habitats. Microbiological investigation of water and sediments from the Vrelo Cave, the Republic of Macedonia [33], revealed mostly the presence of Bacillus spp. strains (83 \%), but, additionally, allochthonic strains were detected, including $P$. penneri, in a water sample taken from a place located $400 \mathrm{~m}$ from the cave entrance and $100 \mathrm{~m}$ deep. Moreover, although physical, chemical, and biochemical parameters indicated a high water quality, big numbers of total and fecal coliform bacteria were observed both in water and in sediment samples, suggesting their contamination from an animal source.

The detection of bacteria belonging to the genus Proteus in drinking water disqualifies its suitability for consumption due to its fecal pollution, which would threaten with waterborne infections. The problem occurs in India. P. vulgaris was claimed to be the main microbial pollutant of drinking water in Rajasthan [140]. Then, in bore well waters in Mysore City, P. mirabilis and $P$. vulgaris strains dominated over the other $\mathrm{H}_{2} \mathrm{~S}$-producing strains (considered as associated to fecal coliforms in drinking water) [93]. Poonia et al. [117] reported on the alarming presence of multidrug resistant $P$. mirabilis and $P$. vulgaris strains among other bacteria in drinking water from springs and streams in the rural areas of Sikkim. Also, in Nigeria, Proteus spp. bacteria were detected in two of five studied well waters, treated as a source of drinking water [1].

P. mirabilis, $P$. vulgaris, and $P$. penneri strains, in addition to other members of Enterobacteriaceae, were recognized as bacteria connected with an anthropic influence, indicating the fecal contamination of rice field water from irrigation channels and rice field plots in Rio Grande do Sul, Brazil [122].

Also, in soil, the presence of Proteus spp. bacteria is regarded as the evidence for its fecal contamination. Srinivasan et al. [138] reported on the isolation of $P$. mirabilis strains from the soil samples from a dairy farm area that was regularly treated with cow manure, but not from the control forest soil samples with no history of agriculture. Trawińska et al. [143] detected both Proteus spp. and E. coli strains in soil samples, collected near or $300 \mathrm{~m}$ from the reproductive layer farm in Poland, although the grounds were not treated with manure or exploited. Thus, it was suggested that the bacteria associated with fecal contamination of soil may have come from other animals, because the soil samples also contained Toxocara spp. eggs, which are not found in birds.

\section{Proteus in Bioremediation and Plant Growth Promotion}

Proteus spp. bacteria, as an element of intestinal microflora of humans and animals, are often treated as zymogens in soil or water. In fact, these proteolytic microorganisms come to these environments with feces or waste, and after digestion of approachable organic matter, they decay due to the lack of nutrients.

However, these microorganisms are also found in such habitats as autochthones, well adapted to the environmental conditions, exhibiting unusual and exceptional metabolic features (Table 4), although this aspect of the genus Proteus lifestyle is less known. An interesting example is a P. mirabilis strain isolated from coastal seawater in China, which was characterized as a heterotrophic nitrifier [158]. The strain effectively removed ammonia $\left(\mathrm{NH}_{4}{ }^{+}\right)$ions by oxidation. Moreover, only trace amounts of $\mathrm{NO}_{2}{ }^{-}$and $\mathrm{NO}_{3}{ }^{-}$were detectable after cultivation as the ions were simultaneously reduced by the bacterium to gaseous nitrogen $\left(\mathrm{N}_{2}\right)$ in the denitrification processes. The processes and the cell growth were inhibited in the absence of any organic source of carbon. The strain is suggested to be used for toxic $\mathrm{NH}_{4}{ }^{+}-\mathrm{N}$ removal, although its activity in oligotrophic water was limited probably due to the lack of carbon sources. Similar metabolic activity was displayed by the Proteus sp. strain related to P. mirabilis, isolated from effluents from a fish processing plant in India [86]. Simultaneous aerobic nitrification and denitrification leading to the efficient removal of nitrogen by this 
heterotrophic bacterium are suggested to be applied in fish waste treatment.

Proteus spp. bacteria, though well known as opportunistic pathogens, in natural environments show more positive aspects of their existence. They may play a role of effective and specialized plant-growth-promoting rhizobacteria (PGRP) or bioremediators of hydrocarbons, pesticides, herbicides, aromatic compounds, azo dyes, and heavy metals in contaminated environments.

Lipase production is not typical of all Proteus species (Table 1), but the rods in natural environments are able to effectively degrade hydrocarbons, including oils, and to remove these hazardous substances efficiently and inexpensively. Kim et al. [65] reported on a P. vulgaris strain producing extracellular alkaline lipase isolated from soil samples collected near a sewage disposal plant in South Korea. The lipase was stable from $\mathrm{pH} 5$ to 11 and had a maximum activity at $\mathrm{pH}$ 10. Lu et al. [77] isolated from soil in China a P. vulgaris strain which produced alkaline non-position-specific lipase, whereas Whangsuk et al. [153] found in a waste-sludge from beer factory in Taiwan a Proteus sp. strain actively giving off organic-solvent-tolerant lipase named LipA, which effectively conversed palm oil into biodiesel.

The first report on a Proteus sp. strain which could be useful as a sole degrader of oil hydrocarbons in soil was presented by Hernandez-Rivera et al. [57]. The strain may be presumed to belong to $P$. vulgaris group due to indole production and maltose fermentation abilities observed by the authors (see Table 1). It was found in tropical soil containing total petroleum hydrocarbons (TPHs) in the Tabasco region, Mexico, highly contaminated by oil spills during 20 years of pollution and was able to remove the superficial hydrocarbon layer (the only carbon source) in the culture medium forming a stable emulsion, most probably due to the production of biosurfactants by the strain itself. The results were better than in the medium containing urea (actively utilized by the bacteria; see Table 1). Then, Ibrahim et al. [58] studying soil samples collected from the rhizosphere of legumes planted on crude-oil-contaminated soil in Kaduna, Nigeria, found $P$. mirabilis and $P$. vulgaris strains as belonging to the most active crude oil degraders among the several isolated species, although not displaying biosurfactant production. Earlier, another hydrocarbon degrading P. vulgaris strain had been isolated from newly killed fish samples that were collected near the point of spill in the Niger Delta, where most of the crude oil in Nigeria is found. The isolated strain was able to utilize Bonny light crude oil, diesel, and kerosene, generating organic acids. The finding is promising for this region, where the oil spills are a source of significant air, soil, and water pollution, destroying biodiversity in the ecosystem [105]. Lutz et al. [78] described a wild-type bacterial cocktail marketed as Superbugs ${ }^{\circledR}$ and composed of bacteria belonging to genera Proteus, Bacillus, Pseudomonas, Citrobacter, and
Enterobacter, as effective in the biodegradation of ethyl biodiesel made from palm triacylglycerols in Costa Rica.

There are several reports on Proteus spp. strains able to biodegrade polyaromatic hydrocarbons (PAHs). The genus Proteus dominated after $E$. coli in the group of 60 different bacterial strains able to degrade hydrocarbons, classified as hazardous waste in soil (benzene, toluene, octane, heptanes, biphenyl, naphthalene, camphor, and phenanthrene), isolated from soil samples near different petrol pumps of Karachi City, Pakistan [139]. The genes responsible for the hydrocarbon degradation ability were located either chromosomally or extra-chromosomally. The plasmid location is promising for bioremediation processes since the genes can be conjugated to other microorganisms in polluted environments. Ceyhan [22] reported on a $P$. vulgaris strain, isolated from biofilm in wastewater of the petrochemical industry in Turkey, which was effective in the degradation of pyrene (four-ring PAH) as a sole source of carbon and energy. Moreover, the degradation of this highly toxic and carcinogenic hydrocarbon resulted in non-toxic and non-accumulating metabolites, proving a big biodegradation potential of the strain.

Gasoline-contaminated soil from a gas station in Chihuahua, Mexico, was the habitat of a P. mirabilis strain degrading with medium efficiency methyl tert-butyl ether (MTBE), which is a toxic synthetic compound added to gasoline in a high concentration of $15 \%$, as a blending component [90]. Next, a P. mirabilis strain was found, which was able to efficiently degrade phenol as a sole carbon and energy source in an oil-contaminated soil sample collected in India [88]. Sanuth et al. [128] identified a P. mirabilis strain which was the most effective in $\varepsilon$-caprolactam degradation among the bacteria isolated from soils collected from the major solid waste dumpsites in Lagos State, Nigeria. $\varepsilon$-Caprolactam is a monomer for nylon-6 production, found in wastewater effluents from nylon-producing factories, toxic to plants, animals, and humans. The strain seems to be a potential candidate for its bioremediation.

Bacteria from the genus Proteus solely or in consortia also display an ability to neutralize different toxic herbicides and pesticides that may cause heavy pollution in terrestrial and aquatic ecosystems, especially when inappropriately used. $P$. vulgaris from a mouse intestine was one of the first reported bacteria solely able to reduce dichloro-diphenyltrichloroethane (DDT) pesticide to dichloro-diphenyldichloroethane (DDD) [41]. Although DDD is also a toxic pesticide, its production is the first step during the degradation and mineralization of DDT, and it is utilized in further transformations.

Correa and Steen [27] found a P. mirabilis strain to be the fastest degrader of the propanil (a commonly used herbicide) among the natural microflora inhabiting a pristine lake in northeast Georgia, USA, followed by the bacteria belonging to the genera Aeromonas, Aerobacter, and Acinetobacter. 
Proteus spp. bacteria isolated from the rhizosphere of rice in West Bengal, India, used hexachlorocyclohexane $(\mathrm{HCH})$ pesticide [30] or phorate insecticide [31, 32] as a source of carbon and energy, and the addition of these chemicals to soil intensified the growth of bacteria. It is worth mentioning that Proteus spp. were the only members of the family Enterobacteriaceae isolated from these soil samples besides typical soil bacteria, actinomycetes, and fungi. Another example of autochthonous Proteus sp. strain, isolated from phoratecontaminated soil in India and able to degrade this insecticide, was described by Bano and Musarrat [11]. The strain exhibited also siderophore production, phosphate solubilizing capacities, and strong antifungal effect on phytopathogen Fusarium oxysporum, thus indicating the potential possibilities of its exploitation as PGPR as well.

The presence of $P$. vulgaris and Proteus sp. strains in microbial consortia capable of pesticide degradation was detected in highly contaminated soils in Colombia [116]. From soil samples exposed to different kinds of waste (including hazardous ones), a microbial consortium was isolated composed of ten strains, including P. vulgaris and Proteus sp. The consortium was able to degrade two widely used organophosphatic pesticides, chlorpyrifos and methyl parathion, both in culture medium and in soil. A similar bacterial consortium was found in highly contaminated soil samples from Moravia, Medellin, an area that was used as a garbage dump from 1974 to 1982 [115]. The consortium was able to degrade methyl parathion and p-nitrophenol as the only source of carbon and to decrease their toxicity in the medium and in soil at different depths.

Azo dyes frequently used for textile dyeing and paper printing and their metabolites present in effluents may be toxic, mutagenic, or carcinogenic. Their physicochemical neutralization is costly, while biological degradation is cost-effective and friendly to the environment, but difficult. For that reason, identification of the effective Proteus spp. degraders is a promising perspective for the environmental protection. Patil et al. [112] have isolated a Proteus sp. strain (related to P. vulgaris) from a waste site of the textile industry in India, which was capable of degrading seven textile azo dyes, but the most effective decolorization and detoxification of Navy Blue Rx were observed due to the induction of laccase and other enzymes. Chen et al. [25] isolated from sludge, obtained from a dyeing wastewater treatment plant in Taiwan, a $P$. mirabilis strain exhibiting a great capacity of efficient enzymatic reduction and decolorization associated with the biosorption of deep red RED RBN as well as deep black BK-5 azo dyes. Furthermore, Olukanni et al. [106] isolated from municipal dump site soil near Lagos, Nigeria, a $P$. mirabilis strain able to degrade a Reactive Blue 13 azo dye to phyto-non-toxic products. However, its laccase (the azodye-degrading oxidoreductase) activity was 70 -fold lower than that of another very effective strain, $P$. hauseri, isolated from the Chiao-His hot spring in Taiwan [95, 157]. It effectively decolorized several mono- and di-azo dyes [23, 24] and was copper-tolerant as its laccase was a copper-induced enzyme with thermophilic and acidophilic properties [159]. However, the presence of copper in the environment reduced the swarming activity of the bacterium [96]. The isolate is the first reported non-pathogenic strain in the species $P$. hauseri, coming from natural water habitat.

There are more reports on the high tolerance of Proteus spp. bacteria to copper and other heavy metals. Ge et al. [45], from the East Sea (China) contaminated by chromate, isolated a Proteus sp. strain (related to P. penneri and P. hauseri) which was highly tolerant to $\mathrm{Cr}$ (VI) and could significantly reduce the amounts of this toxic metal in seawater. Hassen et al. [55] in Tunisia isolated from wastewater many Gram-negative bacteria with dominating Pseudomonas spp. and P. mirabilis strains, highly tolerant especially to copper and also to chromium, cobalt, cadmium, zinc, and mercury. Also, a highly resistant to several heavy metals (including mercury, copper, zinc, cadmium, cobalt, silver, and others) $P$. mirabilis strain was identified in wastewater samples from Casablanca City, Moroccco, also exhibiting resistance to naphthalene, anthracene, and antibiotics [40]. Another strongly copper resistant strain identified as $P$. vulgaris and isolated from soil samples collected near the Panki power plant in Kampur, India, was reported by Rani et al. [120]. The strain used to inoculate pigeon pea (Cajanus cajan) seeds protected the pea against the inhibitory effect of copper, reducing its amounts both in soil and in the plant. Moreover, the bacterium was able to produce siderophores providing pigeon pea with iron and preventing chlorosis.

There are more examples of soil Proteus spp. strains beneficial to plants (Table 3). Islam et al. [60] reported on a $P$. mirabilis strain highly resistant to zinc, found in agricultural field soil, irrigated with industrial effluents in Faisalabad City, Pakistan. The strain was able to block zinc absorption by maize (Zea mays) roots, reduce oxidative stress in the plant, and increase its tolerance to zinc, promoting maize growth in the presence of the heavy metal. Simultaneously, the bacterium enhanced phytoremediation processes conducted by this copper-resistant plant. Rau et al. [121] characterized a $P$. mirabilis strain isolated from rhizosphere of wild grass Saccharum ravennae colonizing fly ash dumps in Delhi, India. The strain displayed strong resistance to arsenic and was medium resistant to copper, chromium, cobalt, cadmium, zinc, mercury, nickel, and lead. Additionally, the strain produced siderophores with great capacity and was an active phosphate solubilizer, thus enhancing the growth of grass. Similarly, a Proteus sp. strain from a rice field in Pakistan inoculated on wheat seeds effectively solubilized rock phosphate composted with poultry litter, stimulating the plant growth [14]. Yet, rhizobacterial $P$. vulgaris strains, identified in acidic soil from a tea (Camellia sinensis) plantation in India, expressed 
siderophore production and antifungal properties both in acidic and in neutral $\mathrm{pH}$ conditions [12]. The strains successfully protected three tested species of leguminous plants from the pathogenic fungus Fusarium moniliformae; when the seeds were bacterized during the sowing, they were able to colonize roots and promote the growth of host plants. Lu et al. [76] found in cow dung in China P. penneri strains which produced volatile organic compounds killing within $1 \mathrm{~h} 98-100 \%$ of tested nematodes: soil Caenorhabditis elegans and plantpathogenic Meloidogyne incognita, thus expressing the possibility of being used as a protecting plant biocontrol agent. Yu and Lee [156] stated that indole production by the $P$. vulgaris strain (Table 1) isolated from the rhizosphere of halophyte glasswort (Salicornia herbacea L.) effectively promoted the growth of Chinese cabbage seedling (Brassica campestris ssp. pekinensis), while Bhattacharyya et al. [13] reported that the same strain stimulated the growth of Arabidopsis thaliana (a small flowering plant from the family Brassicacae) by indole production influencing the auxin, cytokinin, and brassinosteroid signaling pathways.

These promising results open wider possibilities of using specialized Proteus spp. strains as bioremediators and PGPR.

\section{Conclusion}

Bacteria from the genus Proteus are well known as human opportunistic pathogens and intestinal microorganisms indicating fecal pollution of water or soil. Their presence in drinking water poses a threat of infection. On the other hand, the bacilli are believed to play an important role in removing organic pollutants of animal origin, especially fecal ones, by decomposing the dead organic matter in water or soil environments. Their proteolytic and ureolytic properties may place the bacteria among the most efficient saprobes taking part in the enrichment of manured soils in ammonia salts and therefore participating in the nitrogen cycle. However, the significance of these microorganisms in the mineralization processes of nitrogen-containing organic compounds is not obvious. This aspect of their metabolism requires more research. It would be reasonable to establish their exact contribution as destruents to the circulation of matter in nature.

Proteus spp. strains are sometimes found to co-operate with higher organisms, playing a role of animal and plant symbionts. Their antagonistic or commensal relationships with numerous animals have also been documented. However, environments other than the human body are less recognized as habitats of Proteus spp. rods. In the future, more attention should be paid to the interdependences between Proteus spp. and animals or plants coexisting with the bacteria in the environment. Relatively little information is available also about the mutual relations between Proteus spp. bacilli and other bacteria in natural habitats. Establishing what kind of relationships these are and which organisms benefit from this system is the basis for determining the reasons why the bacilli occur in a given ecosystem and the consequences of their activity.

Nowadays, molecular techniques provide proper tools to investigate the microorganisms in their natural habitats. The differences in the biochemical features do not exclude the strain from a genus as long as the similarities on the genome level are big enough. It is important to employ molecular techniques in the identification of Proteus spp. strains, especially those belonging to the new genomospecies, the biochemical differentiation of which is impossible. Metagenomic analysis of soil and water environments as well as of different niches in human, animal, and plant organisms using proper primer sequences may reveal the presence of Proteus spp. strains in these habitats even if they exhibit atypical activities and play unusual roles.

Proteus spp. bacteria often display exceptional metabolic features, allowing them to adapt to various conditions and reach distant niches in natural environments where they may be recognized as autochthons. Although the genus is usually not mentioned among PGPR or bioremediators, Proteus spp. environmental strains possess the abilities of immobilization of heavy metals, utilization of toxic pollutants, and plant growth stimulation, as well as nematicidal and fungicidal properties. Numerous examples suggest that the application of these microorganisms may be an effective way of protecting plants and groundwater. The biological treatment of polluted natural environments is more efficient and costeffective than physicochemical methods and can be used in large areas due to simple application and an ability to remove pollution completely. Bioremediation could involve not only the stimulation of the natural autochthonic Proteus spp. strains but also introducing these microorganisms to the polluted environment.

However, it is important to remember that the bacteria belonging to the genus Proteus are opportunistic human and animal pathogens. It would be useful and interesting to compare the features (especially virulence factors, serotypes, metabolic apparatus, and the antibiotic resistance) expressed by Proteus spp. clinical isolates and by the strains existing in animal, soil, and water ecosystems. Do environmental Proteus spp. strains differ significantly from clinical ones? Do they possess genes coding the factors of pathogenicity identified in the strains isolated from patients? If so, do they express these factors and how do they use them in non-pathogenic conditions? What is the risk of transformation of a strain which could be used in bioremediation and environmental protection into a virulent one posing a threat to the animals or humans inhabiting the area? Do the environmental strains carry antibiotic resistance genes, which might lead to the transfer of these genes into other microorganisms in the environment? Answers to these questions could explain which 
factors contribute to and in what way they are important in different lifestyles presented by Proteus spp. bacteria in various environments.

Acknowledgments I thank Prof. Antoni Różalski for critical reading of the manuscript.

Open Access This article is distributed under the terms of the Creative Commons Attribution 4.0 International License (http:// creativecommons.org/licenses/by/4.0/), which permits unrestricted use, distribution, and reproduction in any medium, provided you give appropriate credit to the original author(s) and the source, provide a link to the Creative Commons license, and indicate if changes were made.

\section{References}

1. Aboh EA, Giwa FJ, Giwa A (2015) Microbiological assessment of well waters in Samaru, Zaria, Kaduna, State, Nigeria. Ann Afr Med 14:32-38

2. Abu-Samra MT, Shuaib YA (2014) A study on the nature of association between Demodex mites and bacteria involved in skin and meibomian gland lesions of demodectic mange in cattle. Vet Med Int. doi:10.1155/2014/413719

3. Akoachere J-FTK, Oben PM, Mbivnjo BS, Ndip LM, Nkwelang G, Ndip RN (2008) Bacterial indicators of pollution of the Douala lagoon, Cameroon: public health implications. Afr Health Sci 8(2):85-89

4. Alagesan P, Ashok KB, Muthukrishnan J, Gunasekaran P (2003) Isolation and characterization of gut bacteria of millipede, Xenobolus carnifex (Fabricius). Indian J Microbiol 43:111-113

5. Al-Bahry SN, Al-Zadjali MA, Mahmoud IY, Elshafie AE (2012) Biomonitoring marine habitats in reference to antibiotic resistant bacteria and ampicillin resistance determinants from oviductal fluid of the nesting green sea turtle, Chelonia mydas. Chemosphere 87:1308-1315

6. Anand AAP, Sripathi K (2004) Digestion of cellulose and xylan by symbiotic bacteria in the intestine of the Indian flying fox (Pteropus giganteus). Comp Biochem Physiol 139:65-69

7. Arbatsky NP, Drzewiecka D, Palusiak A, Shashkov AS, Zabłotni A, Siwińska M, Knirel YA (2013) Structure of a Kdo-containing O polysaccharide representing Proteus O79, a newly described serogroup for some clinical Proteus genomospecies isolates from Poland. Carbohydr Res 379:100-105

8. Armbruster CE, Mobley HLT (2012) Merging mythology and morphology: the multifaceted lifestyle of Proteus mirabilis. Nat Rev Microbiol 10(11):743-754

9. Awad-Alla ME, Abdien HMF, Dessouki AA (2010) Prevalence of bacteria and parasites in white ibis in Egypt. Vet Ital 46(3):277286

10. Awong-Taylor J, Craven KS, Griffiths L, Bass C, Muscarella M (2008) Comparison of biochemical and molecular methods for the identification of bacterial isolates associated with failed loggerhead sea turtle eggs. J Appl Microbiol 104:1244-1251

11. Bano N, Musarrat J (2003) Isolation and characterization of phorate degrading soil bacteria of environmental and agronomic significance. Lett Appl Microbiol 36:349-353

12. Barthakur M, Bezbaruah B (1999) Plant beneficial effect of two strains of Proteus vulgaris isolated from tea plantations. Indial J Exp Biol 37:919-924

13. Bhattacharyya D, Garladinne M, Lee Y-H (2015) Volatile indole produced by rhizobacterium Proteus vulgaris JBLS202 stimulates growth of Arabidopsis thaliana through auxin, cytokinin, and brassinosteroid pathways. J Plant Growth Regul 34:158-168

14. Billah M, Bano A (2015) Role of plant growth promoting rhizobacteria in modulating the efficiency of poultry litter composting with rock phosphate and its effect on growth and yield of wheat. Waste Manag Res 33(1):63-72

15. Bittar F, Keita MB, Lagier J-C, Peeters M, Delaporte E, Raoult D (2014) Gorilla gorilla gorilla gut: a potential reservoir of pathogenic bacteria as revealed using culturomics and molecular tools. Sci Rep. doi:10.1038/srep07174

16. Blaylock RS (2001) Normal oral bacterial flora from some southern African snakes. Onderstepoort J Vet Res 68(3):175-182

17. Boari CA, Pereira GI, Valeriano C, Silva BC, de Morais VM, Figueiredo HCP, Piccoli RH (2008) Bacterial ecology of tilapia fresh fillets and some factors that can influence their microbial quality. Cienc Tecnol Aliment 28(4):863-867

18. Bohova J, Majtan J, Majtan V, Takac P (2014) Selective antibiofilm effects of Lucilia sericata larvae secretions/ excretions against wound pathogens. Evid Based Complement Alternat Med. doi:10.1155/2014/857360

19. Budding AE, Ingham CJ, Bitter W, Vandenbroucke-Grauls CM, Schneeberger PM (2009) The Dienes phenomenon: competition and territoriality in swarming Proteus mirabilis. J Bacteriol 191: 3892-3900

20. Cao H, He S, Lu L, Yang X, Chen B (2014) Identification of a Proteus penneri isolate as the causal agent of red body disease of the cultured white shrimp Penaeus vannamei and its control with Bdellovibrio bacteriovorus. Antonie Van Leeuwenhoek 105:423430

21. Cardarelli L, Saak C, Gibbs KA (2015) Two proteins form a heteromeric bacterial self-recognition complex in which variable subdomains determine allele-restricted binding. mBio 6:e025115

22. Ceyhan N (2012) Biodegradation of pyrene by a newly isolated Proteus vulgaris. Sci Res Essays 7(1):66-77

23. Chen B-Y, Wang Y-M, Ng I-S (2011) Understanding interactive characteristics of bioelectricity generation and reductive decolorization using Proteus hauseri. Bioresour Technol 102:1159-1165

24. Chen B-Y, Zhang M-M, Chang C-T, Ding Y, Lin K-L, Chiou C-S, Hsueh C-C, Xu H (2010) Assessment upon azo dye decolorization and bioelectricity generation by Proteus hauseri. Bioresour Technol 101(12):4737-41

25. Chen K-C, Huang W-T, Wu J-Y, Houng J-Y (1999) Microbial decolorization of azo dyes by Proteus mirabilis. J Ind Microbiol Biotechnol 23:686-690

26. Chow AW, Taylor PR, Yoshikawa TT, Guze LB (1979) A nosocomial outbreak of infections due to multiply resistant Proteus mirabilis: role of intestinal colonization as a major reservoir. $\mathrm{J}$ Infect Dis 139(6):621-627

27. Correa IE, Steen WC (1995) Degradation of propanil by bacterial isolates and mixed populations from a pristine lake. Chemosphere 30(1):103-116

28. Dang H, Ren J, Song L, Sun S, An L (2008) Diverse tetracycline resistant bacteria and resistance genes from coastal waters of Jiaozhou Bay. Microb Ecol 55:237-246

29. Dang H, Ren J, Song L, Sun S, An L (2008) Dominant chloramphenicol-resistant bacteria and resistance genes in coastal marine waters of Jiaozhou Bay, China. World J Microbiol Biotechnol 24:209-217

30. Das AC, Chakravarty A, Sukul P, Mukherjee D (1995) Insecticides: their effect on microorganisms and persistence in rice soil. Microbiol Res 150:187-194

31. Das AC, Chakravarty A, Sukul P, Mukherjee D (2003) Influence and persistence of phorate and carbofuran insecticides on microorganisms in rice field. Chemosphere 53:1033-1037 
32. Das AC, Mukherjee D (2000) Soil application of insecticides influences microorganisms and plant nutrients. Appl Soil Ecol 14: $55-62$

33. Davalieva K, Kungulovski D, Atanasova-Pancevska N, Bojkovska R, Stafilov T, Efremov GD (2011) Microbiological and chemical characteristics of water and sediment from Vrelo Cave, Republic of Macedonia. Prilozi 32(2):169-186

34. Drzewiecka D, Arbatsky NP, Shashkov AS, Staczek P, Knirel YA, Sidorczyk Z (2008) Structure and serological properties of the Oantigen of two clinical Proteus mirabilis strains classified into a new Proteus O77 serogroup. FEMS Immunol Med Microbiol 54: 185-194

35. Drzewiecka D, Arbatsky NP, Stączek P, Shashkov AS, Knirel YA, Sidorczyk Z (2010) Structural and serological studies of the Opolysaccharide of strains from a newly created Proteus $\mathrm{O} 78$ serogroup prevalent in Polish patients. FEMS Immunol Med Microbiol 58:269-276

36. Drzewiecka D, Sidorczyk Z (2005) Characterization of Proteus penneri species - human opportunistic pathogens. Post Mikrobiol 44:113-126 (in Polish)

37. Drzewiecka D, Zych K, Sidorczyk Z (2004) Characterization and serological classification of a collection of Proteus penneri clinical strains. Arch Immunol Ther Exp 52:121-128

38. Eze CA, Ugwu J, Eze JI, Nnaji TO, Nweze NE, Ngene AA (2014) Characterisation of the bacterial isolates from transmissible venereal tumor lesions of dogs and their antibiogram resistance in Nsukka area, Southeastern Nigeria. Comp Clin Pathol 23:641645

39. Fernandez-Delgado M, Contreras M, Garcia-Amado A, Gueneau P, Suarez P (2007) Occurrence of Proteus mirabilis associated with two species of Venezuelan oysters. Rev Inst Med Trop S Paulo 49(6):355-359

40. Filali BK, Taoufik J, Zeroual Y, Dzairi FZ, Talbi M, Blaghen M (2000) Waste water bacterial isolates resistant to heavy metals and antibiotics. Curr Microbiol 41:151-156

41. Foght J, April T, Biggar K, Aislabie J (2001) Bioremediation of DDT-contaminated soils: a review. Bioremediat J 5(3):225-246

42. Foti M, Giacopello C, Bottari T, Fisichella V, Rinaldo D, Mammina C (2009) Antibiotic resistance of Gram negatives isolates from loggerhead sea turtles (Caretta caretta) in the central Mediterranean Sea. Mar Pollut Bull 58:1363-1366

43. Foti M, Rinaldo D, Guercio A, Giacopello C, Aleo A, De Leo F, Fisichella V, Mammina C (2011) Pathogenic microorganisms carried by migratory birds passing through the territory of the island of Ustica, Sicily (Italy). Avian Pathol 40(4):405-409

44. Gaastra W, van Oosterom RAA, Pieters EWJ, Bergmans HEN, van Dijk L, Agnes A, ter Huurne HM (1996) Isolation and characterization of dog uropathogenic Proteus mirabilis strains. Vet Microbiol 48:57-71

45. Ge S, Dong X, Zhou J, Ge S (2013) Comparative evaluations on bio-treatment of hexavalent chromate by resting cells of Pseudochrobactrum sp. and Proteus sp. in wastewater. J Environ Manag 126:7-12

46. Giacopello C, Foti M, Fisichella V, Lo Piccolo F (2015) Antibiotic-resistance patterns of Gram-negative bacterial isolates from breeder canaries (Serinus canaria domestica) with clinical disease. J Exot Pet Med 24:84-91

47. Giammanco GM, Grimont PA, Grimont F, Lefevre M, Giammanco G, Pignato S (2011) Phylogenetic analysis of the genera Proteus, Morganella, and Providencia by comparison of гро $B$ gene sequence of type and clinical strains suggests the reclassification of Proteus myxofaciens in a new genus, Cosenzaea gen. nov., as Cosenzaea myxofaciens comb. nov. Int J Syst Evol Microbiol 61:1638-1644

48. Gibbs KA, Greenberg EP (2011) Territoriality in Proteus: advertisement and aggression. Chem Rev 111(1):188-194
49. Gibbs KA, Wenren LM, Greenberg EP (2011) Identity gene expression in Proteus mirabilis. J Bacteriol 193:3286-3292

50. Graça AP, Viana F, Bondoso J, Correia MI, Gomes L, Humanes M, Reis A, Xavier JR, Gaspar H, Lage OM (2015) The antimicrobial activity of heterotrophic bacteria isolated from the marine sponge Erylus deficiens (Astrophorida, Geodiidae). Front Microbiol 6:389. doi:10.3389/fmicb.2015.00389

51. Gupta AK, Nayduch D, Verma P, Shah B, Ghate HV, Patole MS, Shouche YS (2012) Phylogenetic characterization of bacteria in the gut of house flies (Musca domestica L.). FEMS Microbiol Ecol 79:581-593

52. Hačene H, Rafa F, Chebhouni N, Boutaiba S, Bhatnagar T, Baratti JC, Ollivier B (2004) Biodiversity of prokaryotic microflora In El Golea Salt lake, Algerian Sahara. J Arid Environ 58:273-284

53. Hacioglu N, Tosunoglu M (2014) Determination of antimicrobial and heavy metal resistance profiles of some bacteria isolated from aquatic amphibian and reptile species. Environ Monit Assess 186: 407-413

54. Hariharan H, Matthew V, Fountain J, Snell A, Doherty D, King B, Shemer E, Oliveira S, Sharma RN (2011) Aerobic bacteria from mucous membranes, ear canals, and skin wounds of feral cats in Grenada, and the antimicrobial drug susceptibility of major isolates. Comp Immunol Microbiol Infect Dis 34(2):29-34

55. Hassen A, Saidi N, Cherif M, Boudabous A (1998) Resistance of environmental bacteria to heavy metals. Bioresour Technol 64:715

56. Hawkey PM, Penner JL, Linton AH, Hawkey CA, Crisp LJ, Hinton M (1986) Speciation, serotyping, antimicrobial sensitivity and plasmid content of Proteeae from the environment of calfrearing units in South West England. J Hyg Camb 97:405-417

57. Hernandez-Rivera MA, Ojeda-Morales ME, Martinez-Vazquez JG, Villegas-Cornelio VM, Cordova-Bautista Y (2011) Optimal parameters for in vitro development of the hydrocarbonoclastic microorganism Proteus sp. J Soil Sci Plant Natur 11(1):29-43

58. Ibrahim ML, Ijah UJJ, Manga SB, Bilbis LS, Umar S (2013) Production and partial characterization of biosurfactant produced by crude oil degrading bacteria. Int Biodeterior Biodegrad 81:28-34

59. Ikeobi CC, Ogunsanya TO, Rotimi VO (1996) Prevalence of pathogenic role of Morganella-Proteus-Providencia-group of bacteria in human faeces. Afr J Med Med Sci 25(1):7-12

60. Islam F, Yasmeen T, Riaz M, Arif MS, Ali S, Raza SH (2014) Proteus mirabilis alleviates zinc toxicity by preventing oxidative stress in maize (Zea mays) plants. Ecotoxicol Environ Saf 110: 143-152

61. Jahantigh M (2010) Bacteriological study of dead-in-shell embryos of ostrich. Iran J Vet Res 11(1):88-90

62. Jahantigh M (2012) A study of bacteriologic status of infertile ostrich (Struthio camelus) eggs. Comp Clin Pathol 21:1049-1051

63. Janda JM, Abbott SL, Khashe S, Probert W (2001) Biochemical identification and characterization of DNA groups within the Proteus vulgaris complex. J Clin Microbiol 39(4):1231-1234

64. Kefalas E, Castritsi-Catharios J, Miliou H (2003) Bacteria associated with the sponge Spongia officinalis as indicators of contamination. Ecol Indicators 2:339-343

65. Kim H-K, Lee J-K, Kim H, Oh T-K (1996) Characterization of an alkaline lipase from Proteus vulgaris K80 and the DNA sequence of the encoding gene. FEMS Microbiol Lett 135:117-121

66. Kitamikado M, Lee Y-Z (1975) Chondroitinase-producing bacteria in natural habitats. Appl Microbiol 29(3):414-421

67. Knirel YA, Perepelov AV, Kondakova AN, Senchenkova SN, Sidorczyk Z, Różalski A, Kaca W (2011) Structure and serology of O-antigens as the basis for classification of Proteus strains. Innate Immun 17:70-96

68. Kobashi Y, Hasebe A, Nishio M, Uchiyama H (2007) Diversity of tetracycline resistance genes in bacteria isolated from various agricultural environments. Microbes Environ 22(1):44-51 
69. Kroemer S, Garh FE, Galland D, Petit J-L, Woehrle F, Boulouis HJ (2014) Antibiotic susceptibility of bacteria isolated from infections in cats and dogs throughout Europe (2002-2009). Comp Immunol Microbiol Infect Dis 37:97-108

70. Kumar R, Swaminathan TR, Kumar RG, Dharmaratnam A, Basheer VS, Jena JK (2015) Mass mortality in ornamental fish, Cyprinus carpio koi caused by a bacterial pathogen, Proteus hauseri. Acta Trop 149:128-134

71. Kwiecińska-Piróg J, Bogiel T, Gospodarek E, Kasprzak M, Jerzak L, Kamiński P (2011) The susceptibility of Proteus mirabilis strains isolated from white stork (Ciconia ciconia). Med Dosw Mikrobiol 63:139-144 (in Polish)

72. Larsson P (1984) Serology of Proteus mirabilis and Proteus vulgaris. Meth Microbiol 14:187-214

73. Lecomte V, Kaakoush NO, Maloney CA, Raipuria M, Huinao KD, Mitchell HM, Morris MJ (2015) Changes in gut microbiota in rats fed a high fat diet correlate with obesity-associated metabolic parameters. PloS One 10(5), doi:10.1371/journal.pone. 0126931

74. de Louvois J (1969) Serotyping and the Dienes reaction on Proteus mirabilis from hospital infections. J Clin Pathol 22:263268

75. Lowe BA, Marsh TL, Isaacs-Cosgrove N, Kirkwood RN, Kiupel M, Mulks MH (2011) Microbial communities in the tonsils of healthy pigs. Vet Microbiol 147:346-357

76. Lu H, Wang X, Zhang K, Lu Y, Zhou L, Li G (2014) Identification and nematicidal activity of bacteria isolated from cow dung. Ann Microbiol 64:407-411

77. Lu Y, Lin Q, Wang J, Wu Y, Bao W, Lv F, Lu Z (2010) Overexpression and characterization in Bacillus subtilis of a positionally nonspecific lipase from Proteus vulgaris. J Ind Microbiol Biotechnol 37:919-925

78. Lutz G, Chavarria M, Arias ML, Mata-Segreda JF (2006) Microbial degradation of palm (Elaeis giuneensis) biodiesel. Rev Biol Trop 54(1):59-63

79. Ma Q, Fonseca A, Liu W, Fields AT, Pimsler ML, Spindola AF, Tarone AM, Crippen TL, Tomberlin JK, Wood TK (2012) Proteus mirabilis interkingdom swarming signals attract blow flies. ISME J 6:1356-1366

80. Maleki-Ravasan N, Oshaghi MA, Hajikhani S, Saeidi S, Akhavan AA, Gerami-Shoar M, Shirazi MH, Yakhchali B, Rassi Y, Afshar D (2014) Aerobic microbial community of insectary population of Phlebotomus papatasi. J Arthropod-Borne Dis 8(1):69-81

81. Manos J, Belas R (2006) The genera Proteus, Providencia, and Morganella. In: Dworkin M, Falkow S, Rosenberg E, Schleifer KH, Stackebrandt E (eds) The Prokaryotes (3rd edn.) Springer pp. 245-269, DOI: 10.1007/0-387-30746-x 12

82. Matyar F, Kaya A, Dinçer S (2008) Antibacterial agents and heavy metal resistance in Gram-negative bacteria isolated from seawater, shrimp and sediment in Iskenderun Bay, Turkey. Sci Total Environ 407:279-285

83. Mekibib B, Abrham E, Kassaye A, Tesfaye D, Amenu K (2015) Clinicopathologic findings associated with urinary tract problems in working donkeys, Southern Ethiopia: a case study. Comp Clin Pathol 24:417-422

84. Meyer W, Kacza J, Schnapper A, Verspohl J, Hornickel I, Seeger J (2010) A first report on the microbial colonization of the equine oesophagus. Ann Anat 192(1):42-51

85. Miller SG, Campbell BC, Becnell J, Ehrman L (1995) Bacterial entomopathogens from the Drosophila paulistorum semispecies complex. J Invertebr Pathol 65:125-131

86. Mishra SS, Markande AR, Keluskar RP, Karunasagar I, Nayak BB (2015) Simultaneous nitrification and denitrification by novel heterotrophs in remediation of fish processing effluents. J Basic Microbiol 55:772-779
87. Mohd Masri S, Nazni WA, Lee HL, Tengku RTAR, Subramaniam S (2005) Sterilization of Lucilia cuprina (Wiedemann) maggots used in therapy of intractable wounds. Trop Biomed 22(2):185189

88. Mohite BV, Pawar SP, Morankar A (2011) Isolation, selection and biodegradation profile of phenol degrading bacteria from oil contaminated soil. Bull Environ Contam Toxicol 87(2):143-146

89. Morgenstein RM, Szostek B, Rather PN (2010) Regulation of gene expression during swarmer cell differentiation in Proteus mirabilis. FEMS Microbiol Rev 34:753-763

90. Muňoz-Castellanos LN, Torres-Muňoz JV, Keer-Rendon A, Manzanares-Papayanopoulos LI, Nevarez-Moorillon GV (2006) Aerobic biodegradation of methyl tert-butyl ether (MTBE) by pure bacterial cultures isolated from contaminated soil. World $\mathrm{J}$ Microb Biot 22:851-855

91. Müller H (1986) Occurrence and pathogenic role of MorganellaProteus-Providencia group bacteria in human feces. J Clin Microbiol 23(2):404-405

92. Müller H (1989) The role of Proteeae in diarrhea. Zbl Bakt 272(1):30-35

93. Nagaraju D, Sastri JCV (1999) Confirmed faecal pollution to bore well waters of Mysore city. Environ Geol 38(4):322-326

94. Nazni WA, Seleena B, Lee HL, Jeffery J, Rogayah TAR, Sofian MA (2005) Bacteria fauna from the house fly, Musca domestica (L.). Trop Biomed 22(2):225-231

95. Ng I-S, Zheng X, Chen B-Y, Chi X, Chang C-S (2013) Proteomics approach to decipher novel genes and enzymes characterization of a bioelectricity-generating and dye-decolorizing bacterium Proteus hauseri ZMd44. Biotechnol Bioproc Eng 18:8-17

96. Ng I-S, Zheng X, Wang N, Chen B-Y, Zhang X, Lu Y (2014) Copper response of Proteus hauseri based on proteomic and genetic expression and cell morphology analysis. Appl Biochem Biotechnol 173:1057-1072

97. Nguyen VD, Pham TT, Nguyen THT, Nguyen THX, Hoj L (2014) Screening of marine bacteria with bacteriocin-like activities and probiotic potential for ornate spiny lobster (Panulirus ornatus) juveniles. Fish Shellfish Immunol 40:49-60

98. Nimrat S, Bart AN, Keatsaksit A, Vuthiphandchai V (2008) Microbial flora of sphermatophores from black tiger shrimp (Penaeus monodon) declines over long-term cryostorage. Aquaculture 274:247-253

99. Normand EH, Gibson NR, Reid SWJ, Carmichael S, Taylor DJ (2000) Antimicrobial-resistance trends in bacterial isolates from companion-animal community practice in the UK. Prev Vet Med 46:267-278

100. Novak SM (1998) Foodborne illness - chemical fish and shellfish poisoning. Clin Microbiol Newsl 20(3):17-21

101. Novak SS, Seigl RA (1986) Gram-negative septicemia in American alligators (Alligator mississippiensis). J Wildl Dis 22(4):486-487

102. Nowakiewicz A, Ziółkowska G, Zięba P, Dziedzic BM, Gnat S, Wójcik M, Dziedzic R, Kostruba A (2015) Aerobic bacterial microbiota isolated from the cloaca of the European pond turtle (Emys orbicularis) in Poland. J Wildl Dis 51(1):255-9

103. O'Hara CM, Brenner FW, Miller JM (2000) Classification, identification, and clinical significance of Proteus, Providencia, and Morganella. Clin Microbiol Rev 13:534-546

104. O'Hara CM, Brenner FW, Steigerwalt AG, Hill BC, Holmes B, Grimont PAD, Hawkey PM, Penner JL, Miller JM, Brenner D (2000) Classification of Proteus vulgaris biogroup 3 with recognition of Proteus hauseri sp. nov., nom. rev. and unnamed Proteus genomospecies 4, 5 and 6. Int J Syst Evol Microbiol 50:1869-1875

105. Olajide PO, Ogbeifun LB (2010) Hydrocarbon biodegrading potentials of a Proteus vulgaris strain isolated from fish samples. Am J Applied Sci 7(7):922-928 
106. Olukanni OD, Osuntoki AA, Kalyani DC, Gbenle GO, Govindw SP (2010) Decolorization and biodegradation of Reactive Blue 13 by Proteus mirabilis LAG. J Hazard Mater 184(1-3):290-298

107. Onyango MD, Wandili S, Kakai R, Waindi EN (2009) Isolation of Salmonella and Shigella from fish harvested from the Winam Gulf of Lake Victoria, Kenya. J Infect Dev Ctries 3(2):99-104

108. Oros J, Torrent A, Calabuig P, Deniz S (2005) Diseases and causes of mortiality among sea turtles stranded in the Canary Islands, Spain $(1998$ - 2001). Dis Aquat Org 63:13-24

109. Özoğul F, Küley E, Özoğul Y (2010) Usefulness of API test strips for identification of bacterial flora in blue crab (Callinectes sapidus) caught from Akyatan Lagoon (Adana - Turkey). J Fisheries Sciencescom 4(1):1-7

110. Padaruth SK, Biranjia-Hurdoyal SD (2014) Hygiene practices and faecal contamination of the hands of children attending primary school in Mauritius. Int Health. doi:10.1093/inthealth/ihu080

111. Palusiak A (2013) Immunochemical properties of Proteus penneri lipopolysaccharides - one of the major Proteus sp. virulence factors. Carbohydr Res 380:16-22

112. Patil PS, Phugare SS, Kalyani DC, Surwase SN, Jadhav JP (2012) Bioremediation perspective of Navy Blue Rx-containing effluent by bacterial isolate. Bioremediat J 16(4):185-194

113. Peerbooms PG, Verweij AM, Oe PL, MacLaren DM (1986) Urinary pathogenicity of Proteus mirabilis strains isolated from faeces or urine. Antonie Van Leeuwenhoek 52(1):53-62

114. Pfaller MA, Mujeeb I, Hollis RJ, Jones RN, Doern GV (2000) Evaluation of the discriminatory powers of the Dienes test and ribotyping as typing methods for Proteus mirabilis. J Clin Microbiol 38:1077-1080

115. Pino NJ, Dominguez MC, Peňuela GA (2011) Isolation of a selected microbial consortium capable of degrading methyl parathion and p-nitrophenol from a contaminated soil site. J Environ Sci Health B 46(2): 173-80

116. Pino N, Peňuela G (2011) Simultaneous degradation of the pesticides methyl parathion and chlorpyrifos by an isolated bacterial consortium from a contaminated site. Int Biodeterior Biodegrad 65:827-831

117. Poonia S, Singh TS, Tsering DC (2014) Antibiotic susceptibility profile of bacteria isolated from natural sources of water from rural areas of East Sikkim. Indian J Community Med 39(3):156-160

118. Porres-Osante N, Saenz Y, Somalo S, Torres C (2015) Characterization of beta-lactamases in faecal Enterobacteriaceae recovered from healthy humans in Spain: focusing on AmpC polymorphisms. Microb Ecol 70:132-140

119. Qadripur SA, Schauder S, Schwartz P (2001) Black nails from Proteus mirabilis colonization. Hautarzt 52:658-661 (in German)

120. Rani A, Shouche YS, Goel R (2008) Declination of copper toxicity in pigeon pea and soil system by growth-promoting Proteus vulgaris KNP3 strain. Curr Microbiol 57:78-82

121. Rau N, Mishra V, Sharma M, Das MK, Ahaluwalia K, Sharma RS (2009) Evaluation of functional diversity in Rhizobacterial taxa of a wild grass (Saccharum ravennae) colonizing abandoned fly ash dumps in Delhi urban ecosystem. Soil Biol Biochem 41:813-821

122. Reche MHLR, Fiuza LM (2005) Bacterial diversity in rice-field water in Rio Grande do Sul. Braz J Microbiol 36:253-257

123. Rogers KH (2006) Prevalence of pathogenic enteric bacteria in wild birds associated with agriculture in Humboldt County, California. Dissertation, Humboldt State University, Arcata, California, USA

124. Różalski A, Stączek P (2010) Proteus. In: Liu D (ed) Molecular detection of human bacterial pathogens. Taylor \& Francis Group, LLC, CRC Press, Boca Raton, pp 981-996

125. Różalski A, Torzewska A, Moryl M, Kwil I, Maszewska A, Ostrowska K, Drzewiecka D, Zabłotni A, Palusiak A, Siwińska M, Staczek P (2012) Proteus sp. - an opportunistic bacterial pathogen - classification, swarming growth, clinical significance and virulence factors. Folia Biol Oecol 8:1-17

126. Salyers AA, Gupta A, Wang Y (2004) Human intestinal bacteria as reservoirs for antibiotic resistance genes. Trends Microbiol 12(9):412-416

127. Santoro M, Hernandez G, Caballero M, Garcia F (2006) Aerobic bacterial flora of nesting Green turtles (Chelonia mydas) from Tortuguero National Park, Costa Rica. J Zoo Wildl Med 37(4): 549-552

128. Sanuth HA, Yadav A, Fagade OE, Shouche Y (2013) $\varepsilon$ Caprolactam utilization by Proteus sp. and Bordetella sp. isolated from solid waste dumpsites in Lagos State, Nigeria, first report. Indian J Microbiol 53(2):221-226

129. Senior BW (1977) The Dienes phenomenon: identification of the determinants of compatibility. J Gen Microbiol 102:235-244

130. Senior BW, Leslie DL (1986) Rare occurrence of Proteus vulgaris in faeces: a reason for its rare association with urinary tract infections. J Med Microbiol 21(2):139-144

131. Shek KC, Tsui KL, Lam KK, Crow P, Ng KHL, Ades G, Yip KT, Grioni A, Tan KS, Lung DC, Lam TSK, Fung HT, Que TL, Kam CW (2009) Oral bacterial flora of the Chinese cobra (Naja atra) and bamboo pit viper (Trimeresurus albolabris) in Hong Kong SAR, China. Hong Kong Med J 15:183-190

132. Shojaei H, Shooshtaripoor J, Amiri M (2006) Efficacy of simple hand-washing in reduction of microbial hand contamination of Iranian food handlers. Food Res Int 39:525-529

133. Sidorczyk Z, Toukach FV, Zych K, Arbatsky NP, Drzewiecka D, Ziółkowski A, Shashkov AS, Knirel YA (2002) Structural and serological characterization of the lipopolysaccharide from Proteus penneri 20 and classification of the cross-reacting Proteus penneri strains 10, 16, 18, 20, 32 and 45 in Proteus serogroup O17. Arch Immunol Ther Exp 50:345-350

134. Singh B, Crippen TL, Zheng L, Fields AT, Yu Z, Ma Q, Wood TK, Dowd SE, Flores M, Tomberlin JK, Tarone AM (2014) A metagenomic assessment of the bacteria associated with Lucilia sericata and Lucilia cuprina (Diptera: Calliphoridae). Appl Microbiol Biotechnol. doi:10.1007/s00253-014-6115-7

135. Siwińska M, Levina EA, Ovchinnikova OG, Drzewiecka D, Shashkov AS, Różalski A, Knirel YA (2015) Classification of a Proteus penneri clinical isolate with a unique $\mathrm{O}$-antigen structure to a new Proteus serogroup, O80. Carbohydr Res 407:131-136

136. Smith SI, Opere B, Goodluck HT, Akindolire OT, Folaranmi A, Odekeye OM, Omonigbehin EA (2009) Antibiotic susceptibility pattern of Staphylococcus species isolated from telephone receivers. Singapore Med J 50(2):208-211

137. Snowdon JA, Cliver DO (1996) Microorganisms in honey. Int J Food Microbiol 31:1-26

138. Srinivasan V, Nam H-M, Sawant AA, Headrick SI, Nguyen LT, Oliver SP (2008) Distribution of tetracycline and streptomycin resistance genes and class 1 integron in Enterobacteriaceae isolated from dairy and nondairy farm soils. Microb Ecol 55:184-193

139. Survery S, Ahmad S, Subhan SA, Ajaz M, Rasool SA (2004) Hydrocarbon degrading bacteria from Pakistani soil: isolation, identification, screening and genetical studies. Pak J Biol Sci 7(9):1518-1522

140. Suthar S, Chhimpa V, Singh S (2009) Bacterial contamination in drinking water: a case study in rural areas of northern Rajasthan, India. Environ Monit Assess 159:43-50

141. Svanevik CS, Lunestad BT (2011) Characterization of the microbiota of Atlantic mackerel (Scomber scombrus). Int J Food Microbiol 151:164-170

142. Tatfeng YM, Usuanlele MU, Orukpe A, Digban AK, Okodua M, Oviasogie F, Turay AA (2005) Mechanical transmission of pathogenic organisms: the role of cockroaches. J Vect Borne Dis 42: $129-134$ 
143. Trawińska B, Polonis A, Tymczyna L, Popiołek-Pyrz M, Bombik T, Saba L (2006) Bacteriological and parasitologic pollution of the environment and birth health state around the reproductive layer farm. Annales Universitatis Mariae Curie-Sklodowska, EE, XXIV, 50:371-376

144. Urban JE, Broce A (1998) Flies and their bacterial loads in greyhound dog kennels in Kansas. Curr Microbiol 36:164-170

145. Vazirianzadeh B, Dehghani R, Mehdinejad M, Sharififard M, Nasirabadi N (2014) The first report of drug resistant bacteria isolated from the brown-banded cockroach, Supella longipalpa, in Ahvaz, south-western Iran. J ArthropodBorne Dis 8(1):53-59

146. Wang L, Pan Q, Zhang L, Xue Q, Cui J, Qi C (2008) Investigation of bacterial microorganisms in the conjunctival sac of clinically normal dogs and dogs with ulcerative keratitis in Beijing, China. Vet Ophthalmol 11:145-149

147. Wang Y, Wang Y, Wu C-M, Schwarz S, Shen Z, Zhang W, Zhang Q, Shen J-Z (2011) Detection of the staphylococcal multiresistance gene cfr in Proteus vulgaris of food animal origin. J Antimicrob Chemother 66:2521-2526

148. Wang Y, Zhang S, Yu J, Zhang H, Yuan Z, Sun Y, Zhang L, Zhu Y, Song H (2010) An outbreak of Proteus mirabilis food poisoning associated with eating stewed pork balls in brown sauce, Beijing. Food Control 21:302-305

149. Wannigama DL, Dwivedi R, Zahraei-Ramazani A (2014) Prevalence and antibiotic resistance of Gram-negative pathogenic bacteria species isolated from Periplaneta americana and Blattella germanica in Varanasi, India. J Arthropod-Borne Dis $8(1): 10-20$

150. Wei T, Miyanaga K, Tanji Y (2014) Persistence of antibioticresistant and -sensitive Proteus mirabilis strains in the digestive tract of the housefly (Musca domestica) and green bottle flies (Calliphoridae). Appl Microbiol Biotechnol 98:8357-8566

151. Wenren LM, Sullivan NL, Cardarelli L, Septer AN, Gibbs KA (2013) Two independent pathways for self-recognition in Proteus mirabilis are linked by type VI-dependent export. mBio 4(4):e00374-13
152. Westgate SJ, Percival SL, Knottenbelt DC, Clegg PD, Cochrane CA (2011) Microbiology of equine wounds and evidence of bacterial biofilms. Vet Microbiol 150:152-159

153. Whangsuk W, Sungkeeree P, Thiengmag S, Kerdwong J, Sallabhan R, Mongkolsuk S, Loprasert S (2013) Gene cloning and characterization of a novel highly organic solvent tolerant lipase from Proteus sp. SW1 and its application for biodiesel production. Mol Biotechnol 53:55-62

154. Winsor DK, Bloebaum AP, Mathewson JJ (1981) Gram-negative, aerobic, enteric pathogens among intestinal microflora of wild turkey vultures (Cathartes aura) in West Central Texas. Appl Environ Microbiol 42(6):1123-1124

155. Yong LH, Ambu S, Devi S, Maung M (2008) Detection of protozoan and bacterial pathogens of public health importance in faeces of Corvus spp. (large-billed crow). Trop Biomed 25(2):134-139

156. Yu S-M, Lee YH (2013) Plant growth promoting rhizobacterium Proteus vulgaris JBLS202 stimulates the seedling growth of Chinese cabbage through indole emission. Plant Soil 370:485495

157. Zhang M-M, Chen W-M, Chen B-Y, Chang C-T, Hsueh C-C, Ding Y, Lin K-L, Xu H (2010) Comparative study on characteristics of azo dye decolorization by indigenous decolorizers. Bioresour Technol 101:2651-2656

158. Zhang WW, Andong ZY, Zhang M, Wang QN, Wei YQ, Chen LX (2014) Isolation and characterization of a heterotrophic nitrifier Proteus mirabilis strain V7 and its potential application in $\mathrm{NH}_{4}{ }^{+}-$ N removal. Ann Microbiol 64:1231-1238

159. Zheng X, Ng I-S, Ye C, Chen B-Y, Lu Y (2013) Copper ionstimulated McoA-laccase production and enzyme characterization in Proteus hauseri ZMd44. J Biosci Bioeng 115(4):388-93

160. Zilberstein B, Quintanilha AG, Santos MAA, Pajecki D, Moura EG, Alves PRA, Filho FM, de Souza JAU, Gama-Rodriques J (2007) Digestive tract microbiota in healthy volunteers. Clinics 62(1):47-54

161. Ziółkowska G, Tokarzewski S, Nowakiewicz A, Kosturba A (2006) Bacteriological flora isolated from geese reproductive flocks. Annales Universitatis Mariae Curie-Sklodowska, DD, LXI, 9:5-86 